\title{
Nitrous oxide emissions in maize on mollisols in the Pampas of Argentina
}

\author{
Liliana I. Picone ${ }^{\mathrm{a}}$, Cimelio Bayer ${ }^{\mathrm{b}}$, Cecilia C. Videla ${ }^{\mathrm{a}}$, Roberto H. Rizzalli ${ }^{\text {, }}$, \\ Sheila M. Casanave Ponti ${ }^{\mathrm{d}}$, Fernando H. Andrade ${ }^{\mathrm{a}, \mathrm{c}, \mathrm{d}}$, Fernando O. García ${ }^{\mathrm{a}, *}$ \\ a Facultad de Ciencias Agrarias - Universidad Nacional de Mar del Plata, Ruta 226, Km 73,5, 7620 Balcarce, Buenos Aires, Argentina

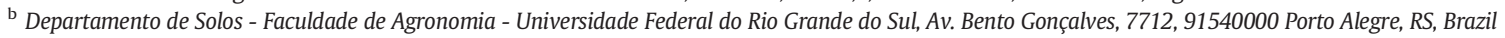 \\ c Instituto Nacional Tecnología Agropecuaria-Estación Experimental Agropecuaria (INTA EEA) Balcarce, Ruta 226, Km 73,5, 7620 Balcarce, Buenos Aires, Argentina \\ d Consejo Nacional de Investigaciones Científicas y Técnicas (CONICET), Buenos Aires, Argentina
}

\section{A R T I C L E I N F O}

\section{Article history:}

Received 26 January 2020

Received in revised form 18 December 2020

Accepted 14 January 2021

\section{Keywords:}

Sustainable intensification

Greenhouse gas emissions

Nitrogen

Mollisols

Soil management

\begin{abstract}
A B S T R A C T
The objectives of this study were i) to measure the soil $\mathrm{N}_{2} \mathrm{O}$ fluxes in a cropping system currently adopted by farmers of the region (FP), and in an ecologically intensified cropping system (EI) over two consecutive maize growing seasons (2011-12 and 2012-13), and ii) to relate $\mathrm{N}_{2} \mathrm{O}$ fluxes to soil factors. Gas fluxes were measured using vented static chambers, from October through April in each season. Fluxes of $\mathrm{N}_{2} \mathrm{O}$ ranged from 3 to $88 \mu \mathrm{g}$ $\mathrm{N}_{2} \mathrm{O}-\mathrm{N} \mathrm{m}^{-2} \mathrm{~h}^{-1}$ in 2011-12, and between 3 and $97 \mu \mathrm{g} \mathrm{N} \mathrm{N}_{2} \mathrm{O}-\mathrm{N} \mathrm{m}^{-2} \mathrm{~h}^{-1}$ in 2012-13. There was a significant $(p<0.05)$ interaction in $\mathrm{N}_{2} \mathrm{O}$ fluxes between management systems and sampling dates $(p<0.05)$ in both seasons. The highest $\mathrm{N}_{2} \mathrm{O}$ fluxes were observed often following a precipitation event and shortly after $\mathrm{N}$ fertilization. While management system impacted on maize grain yield, it had no significant $(p>0.05)$ effect on cumulative $\mathrm{N}_{2} \mathrm{O}$ emissions, which were, on average across two seasons, $558 \mathrm{~g} \mathrm{~N}_{2} \mathrm{O}-\mathrm{N} \mathrm{ha}^{-1}$ for the EI treatment and $578 \mathrm{~g}$ $\mathrm{N}_{2} \mathrm{O}-\mathrm{N} \mathrm{ha}^{-1}$ for the FP treatment. Cumulative $\mathrm{N}_{2} \mathrm{O}$ emissions tended to be $20 \%$ greater over 153 days in 2012-13 compared with over 156 days in 2011-12 mainly due to differences in total and timing precipitations. As there were no differences in cumulative $\mathrm{N}_{2} \mathrm{O}$ emissions between managements but grain yield was higher under EI, this treatment had lower yield-based $\mathrm{N}_{2} \mathrm{O}$ emissions ( $75 \mathrm{~g} \mathrm{~N}_{2} \mathrm{O}-\mathrm{N} \mathrm{Mg}^{-1}$ grain) compared with FP treatment ( $94 \mathrm{~g} \mathrm{~N}_{2} \mathrm{O}-\mathrm{N} \mathrm{Mg}^{-1}$ grain). The results showed that a moderate increase in $\mathrm{N}$ rate $\left(10 \mathrm{~kg} \mathrm{~N} \mathrm{ha}^{-1}\right)$, combined with $\mathrm{N}$ split-application and UAN (urea-ammonium nitrate) as $\mathrm{N}$ source, as well as other crop management practices, can be a viable alternative to improve maize productivity without increasing the $\mathrm{N}_{2} \mathrm{O}$ environmental impact.
\end{abstract}

(c) 2021 Elsevier B.V. All rights reserved.

\section{Introduction}

The steady population and strong economic growth in developing countries have resulted in an increased demand for food, forage, fiber, biofuel, and biomaterials (OECD-FAO, 2018). Grain production should respond to the future global demand either by expanding the land area cultivated or increasing crop productivity on land already under cultivation. However, expansion of area would be limited as agriculture should not develop in marginal lands and ecosystems that are fragile and unlikely to sustain high yield crop production systems (UNEP, 2014). Another option is to implement intensive sustainable production systems with increased crop yields without increasing environmental impacts (Cassman, 1999; Foley et al., 2011; Alexandratos and Bruinsma, 2012; UNEP, 2014; Andrade, 2016).

Intensified agricultural systems require an increased efficiency and effectiveness in the use of resources such as water and nutrients, and

\footnotetext{
* Corresponding author.

E-mail address: fgarcia1957@gmail.com (F.O. García).
}

ecologically-based soil and crop management practices. Increase of around $40-50 \%$ in the use of synthetic fertilizers is expected over the next 50 years and the largest contribution to the global increase in nutrient consumption is that resulting from developing countries (Sutton et al., 2013). However, high levels of nutrient use along with very low efficiency are associated with nutrient losses, which are threats for human health and ecosystem function. Considering the full chain, on average over $80 \%$ of nitrogen $(\mathrm{N})$ and $25-75 \%$ of phosphorus (P) end up lost to the environment, and causing air contamination through emissions of greenhouse gas (GHG), nutrient losses to waters, climate change, land degradation, and biodiversity loss (Sutton et al., 2013).

The demand for agricultural products in the next years should be reached while maintaining or improving the quality of the natural resources involved in agricultural production and the life quality of rural and urban populations (Tillman et al., 2011; Andrade, 2016; Cassman, 2017; Lal, 2019). These requisites are encompassed in the ecological intensification (EI) concept defined by Cassman (1999, 2017), which includes a package of measures that focus on developing sustainable production systems with high production but minimal environmental 
impact. The decisions on agronomic practices based on EI concepts are oriented to closing the gap between water limited yield potential (Yw) and actual yield, and improving natural resource and input productivities using a field-specific management. Soil, crop, and nutrient management under EI would imply changes in practices such as $\mathrm{N}$ rate, time, place or source (IPNI, 2012), which should enhance not only $\mathrm{N}$ use efficiency but also efficiencies of other resources (water, radiation) or inputs (fertilizer, pesticides) and/or result in improved maintenance of soil fertility (i.e., balanced $\mathrm{N}$ budgets) (Caviglia et al., 2019).

Agriculture contributes $23 \%$ of overall global GHG emissions, where $19 \%$ is related to global nitrous oxide $\left(\mathrm{N}_{2} \mathrm{O}\right)$ (IPCC, 2019). Improvement of land management and agricultural practices has the potential to mitigate $\mathrm{N}$ emissions. Nitrification and denitrification processes are the main source of biogenic emissions of $\mathrm{N}_{2} \mathrm{O}$ from soil (Johnson et al., 2007). Factors that significantly influence agricultural $\mathrm{N}_{2} \mathrm{O}$ emissions are $\mathrm{N}$ application rate, crop type, fertilizer type, soil organic carbon (C) content, soil water content, temperature, $\mathrm{pH}$ and texture (Stehfest and Bouwman, 2006; Cosentino et al., 2013; Omonode et al., 2017). There is a large effect of soil moisture content on $\mathrm{N}_{2} \mathrm{O}$ emissions (Farquharson and Baldock, 2008) which have their optimum in the range of $70-80 \%$ water filled pore space (WFPS) depending on soil type (Davidson et al., 2000). However, the complex interaction among soil properties, weather and management practices might explain the high variability of $\mathrm{N}_{2} \mathrm{O}$ emissions in space and time as a result of "hot spots" and "hot moments" (Groffman et al., 2009). This complexity can make difficult to develop generalizations regarding the impact of management system on $\mathrm{N}_{2} \mathrm{O}$ emissions (Snyder et al., 2009).

In Argentina, grain production has increased markedly in the last 25 years mostly as consequence of increases in cropped area under soybean, as well as increases in yields of sunflower and other grains, and increased yields and cropped area of wheat and maize (SAGPy A, 2018; Wingeyer et al., 2015). In the context of the global process of agriculture intensification, the livestock-grain systems in the Pampas of South America have changed to more intensive cropping systems (ManuelNavarrete et al., 2009; Carreno et al., 2012; Wingeyer et al., 2015; Ernst et al., 2016). In addition, there were economic and technological local aspects that promoted the intensification process that led to changes in land-use in the Pampas (Manuel-Navarrete et al., 2009; Wingeyer et al., 2015). Fertilizer use has rapidly increased since the early 90`s, however nutrient budgets are still negative and Pampas agriculture might be considered as medium- or low-input agroecosystems (Norton et al., 2015; García and González Sanjuan, 2016).

The effect of annual cropping systems at Argentina on $\mathrm{N}_{2} \mathrm{O}$ emissions has been explored in different studies. Sainz Rozas et al. (2001) determined the denitrification rates under maize crops, and Alvarez et al. (2012) reported field $\mathrm{N}_{2} \mathrm{O}$ emissions in different crop sequences and tillage systems during a year in the central semiarid Pampas. The later research found that $\mathrm{N}_{2} \mathrm{O}$ fluxes were low during winter but peaked in late spring, and $\mathrm{NO}_{3}-\mathrm{N}$ content was the most important variable to explain $\mathrm{N}_{2} \mathrm{O}$ emissions in the fallow period, while WFPS was in the crop growing period. Measuring the $\mathrm{N}_{2} \mathrm{O}$ fluxes on soybean from sowing to harvest in two seasons, Lewczuk et al. (2017) showed that the $\mathrm{N}_{2} \mathrm{O}$ net balance was +1.45 and $+0.96 \mathrm{~kg} \mathrm{~N}_{2} \mathrm{O}-\mathrm{Nha}^{-1}$ in the first and second season, respectively. Della Chiesa et al. (2019) determined that $\mathrm{N}_{2} \mathrm{O}$ emissions from croplands were higher than background emissions (unmanaged grasslands), but also that background represented an important fraction of cropland emissions (21-32\%), depending on crop type (maize, soybean, double cropped wheat/soybean).

Currently, there is a need of data about the effect of intensive crop management systems on GHG emissions, which are designed to improve the use efficiency and effectiveness of resources and inputs, including cultivars of high yield potential, with resistance and/or tolerance to diseases, pests and herbicides, optimized planting date, population and spacing, and best management practices for fertilizer (source, rate, time, place), in pursuit of sustainable agriculture. Thus, a great challenge is to maximize crop production while at the same time reducing negative impacts on environment, climate and human health by optimizing resource and input use efficiency. Improving resource and input productivity is a key step towards sustainable intensification (Caviglia et al., 2019). Adviento-Borbe et al. (2007) concluded that intensification of cropping systems does not necessarily increase GHG emissions of agricultural systems as long as crops are grown by implementation of best management practices and reaching yields near potential levels, resulting in high resource use efficiency. Zhao et al. (2016) calculated that total GHG emission was $29.8 \%$ lower in ecologically intensified system when compared to current farmer's practice system, by adopting fertilizer right source, right rate, time and placement, and optimizing plant density and plant hybrid selection.

The main objectives of our study were: i) to evaluate the effect of using alternative crop management systems on $\mathrm{N}_{2} \mathrm{O}$ emissions from soil, and ii) to relate $\mathrm{N}_{2} \mathrm{O}$ flux rates to soil factors over two maize growing seasons under conditions of the southern Pampas of Argentina. One management system, termed current farmer practices system, mimic the one adopted by farmers of the region, and the other system, named ecologically intensified cropping system, was recommended according to available information and based to achieve a maize yield of $9 \mathrm{Mg} \mathrm{ha}^{-1}$ with minimal impact on natural resources (air, land, water).

\section{Materials and methods}

\subsection{Site description and experimental design}

The study was conducted from October to April during two consecutive maize growing seasons (2011-12 and 2012-13) at the Agricultural Research Station of the Agricultural Technology National Institute (INTA) located in Balcarce ( $37^{\circ} 45^{\prime} \mathrm{S}$ lat., $58^{\circ} 18^{\prime} \mathrm{W}$ long.; $130 \mathrm{~m}$ above sea level), at Buenos Aires province (Argentina). The climate of the region is mesothermal, subhumid-humid, characterized by a mean annual temperature of $13.9{ }^{\circ} \mathrm{C}$, and an annual precipitation of $955 \mathrm{~mm}$ (period 1971-2007) that is concentrated in spring and autumn. The soil at the experimental site is a complex of Mar del Plata series (fine, mixed, thermic Typic Argiudoll) and Balcarce series (fine, mixed, thermic Petrocalcic Argiudoll). The petrocalcic horizon of Balcarce series is below $0.7 \mathrm{~m}$. The properties at the beginning of the field experiment in the surface soil $(0-20 \mathrm{~cm})$ were: $\mathrm{pH}_{\text {water }}$ of 6.2 , $225 \mathrm{~g} \mathrm{~kg}^{-1}$ of clay, $344.0 \mathrm{~g} \mathrm{~kg}^{-1}$ of silt, $430.6 \mathrm{~g} \mathrm{~kg}^{-1}$ of sand, $26.2 \mathrm{~g} \mathrm{~kg}^{-1}$ of organic C content, $1.9 \mathrm{~g} \mathrm{~kg}^{-1}$ of total $\mathrm{N}$ content, a C/N ratio of 13.7 , and $19 \mathrm{mg} \mathrm{kg}^{-1}$ of available Bray-1 P.

The experiment was established in 2009, being the crop sequence: maize (Zea mays L.) followed by winter wheat (Triticum aestivum L.) and double cropped soybean (Glycine max (L.) Merr). Prior 2009, the site was cropped with annual crops for more than 20 years.

The study compared two managements: 1) current farmer practices (FP) that included management practices implemented by farmers in the production fields of the region, and 2) ecologically intensified management (EI) that was designed according to available information from research in the region. Both treatments, EI and FP, were randomized in a complete block design with three replicates. The two phases of the sequence, wheat/soybean and maize, were included every year, thus our study evaluated maize in one phase in 2011-12 and maize in the other phase in 2012-13.

Agricultural practices for both managements over the two maize growing seasons are summarized in Table 1 . Each management system was a combination of crop management practices: hybrid, plant populations, row spacing, and source, rate and time application of $\mathrm{N}$ and $\mathrm{P}$ fertilizers. In FP treatment, crop management included the average input level as well as most commonly used practices, based on the opinion of expert agronomists who are devoted to advice farmers in the region. Applied $\mathrm{N}$ rate was derived from a $\mathrm{N}$ budget based on soil analysis and a target yield of $7000 \mathrm{~kg} \mathrm{ha}^{-1}$ (average for leading farmers of the region). For the EI treatment, agronomical practices were decided based on 
Table 1

Agricultural practices in maize under current management system (FP) and ecologically intensified management system (EI).

\begin{tabular}{|c|c|c|c|c|}
\hline & \multicolumn{2}{|l|}{ 2011-2012 } & \multicolumn{2}{|l|}{ 2012-2013 } \\
\hline & $\mathrm{FP}$ & EI & $\mathrm{FP}$ & EI \\
\hline Previous crop & Wheat/soybean & & & \\
\hline \multirow[t]{2}{*}{ Hybrid } & KWS KM 3601 & DK 670 MG & KWS KM 3601 & DK $670 \mathrm{MG}$ \\
\hline & RR2 & RR2 & RR2 & RR2 \\
\hline \multirow[t]{2}{*}{ Planting date } & $18-10-2011$ & & 18-10-2012 & \\
\hline & $18-10-2011$ & & $18-10-2012$ & \\
\hline $\begin{array}{l}\text { Plant population } \\
\quad\left(\text { seeds } \mathrm{m}^{-2}\right)\end{array}$ & 6.5 & 8 & 6.4 & 8.2 \\
\hline Row spacing (m) & 0.7 & 0.525 & 0.7 & 0.525 \\
\hline Emergence date & 01-11-2011 & $01-11-2010$ & 27-10-2012 & $30-10-2012$ \\
\hline $\begin{array}{l}\text { DAP application } \\
\text { date }\end{array}$ & $18-10-2011$ & 18-10-2011 & $18-10-2012$ & $18-10-2012$ \\
\hline $\operatorname{DAP}\left(\mathrm{kg} \mathrm{ha}^{-1}\right)$ & 73 & 80 & 73 & 83 \\
\hline $\mathrm{P}\left(\mathrm{kg} \mathrm{ha}^{-1}\right)$ & 15 & 16 & 15 & 16 \\
\hline $\mathrm{N}\left(\mathrm{kg} \mathrm{ha}^{-1}\right)$ & 13 & 14 & 13 & 14 \\
\hline $\begin{array}{l}\text { Urea application } \\
\text { date }\end{array}$ & 05-11-2011 & - & 18-10-2012 & - \\
\hline Urea $\left(\mathrm{kg} \mathrm{ha}^{-1}\right)$ & 80.5 & - & 90.3 & - \\
\hline $\mathrm{N}\left(\mathrm{kg} \mathrm{ha}^{-1}\right)$ & 37 & - & 43 & - \\
\hline $\begin{array}{l}\text { UAN application } \\
\text { date }\end{array}$ & - & 25-11-2011 & - & 28-11-2012 \\
\hline UAN $\left(\mathrm{L} \mathrm{ha}^{-1}\right)$ & - & 125 & - & 142 \\
\hline $\mathrm{N}\left(\mathrm{kg} \mathrm{ha}^{-1}\right)$ & - & 46 & - & 52 \\
\hline $\mathrm{S}\left(\mathrm{kg} \mathrm{ha}^{-1}\right)$ & - & 8.6 & - & 9.7 \\
\hline Total $\mathrm{N}\left(\mathrm{kg} \mathrm{ha}^{-1}\right)$ & 50 & 60 & 56 & 66 \\
\hline
\end{tabular}

DAP: diammonium phosphate; UAN: urea-ammonium nitrate.

previous knowledge and recent research in order to increase grain production together with an increase in resource productivity (Cassman, 1999, 2017) with respect to FP. The particular combination of input level and other management decisions in EI was based on the attainable yield, estimated to be $80 \%$ of Yw, because farmers' yields tend to plateau at 75-85\% of Yw (Van Ittersum et al., 2015; Sadras et al., 2015). For Balcarce, maize Yw was estimated at $12,500 \mathrm{~kg} \mathrm{ha}^{-1}$ by Aramburu Merlos et al. (2015). Further information on the treatments is available at Caviglia et al. (2019).

Treatments were arranged in a randomized complete block design with three blocks, plots were of $50 \mathrm{~m}$ long by $10 \mathrm{~m}$ wide. All operations were carried out with common farmer field equipment.

Maize was grown under no-tillage in both managements. In FP treatment, fertilizer sources were diammonium phosphate (DAP) and urea. The DAP was banded and incorporated into the soil at planting $(5 \mathrm{~cm}$ to the side of the seed and at $2 \mathrm{~cm}$ depth) and urea was surfacebroadcast. In EI treatment, fertilizer sources were DAP and ureaammonium nitrate (UAN). The DAP was banded and incorporated at planting ( $5 \mathrm{~cm}$ to the side of the seed and at $2 \mathrm{~cm}$ depth), while UAN was surface-dribble at the six leaves growth stage (V6) of maize. Timing and $\mathrm{N}$ source for EI were selected to improve synchronicity of $\mathrm{N}$ supply and plant $\mathrm{N}$ uptake, and to reduce potential ammonia volatilization losses, respectively, according to previous research in the region (García et al., 1999; Sainz Rozas et al., 1999, 2001).

\subsection{Nitrous oxide emission measurements}

Emissions of $\mathrm{N}_{2} \mathrm{O}$ were monitored weekly over two maize seasons, from 2 November 2011 to 3 April 2012, and from 31 October 2012 to 5 April 2013. Fluxes of gas from soil were measured, in situ, using non-steady-state, vented and closed chambers composed of a base and cap (Parkin and Venterea, 2010). Bases made with rings of polyvinyl chloride (30 cm diameter and $15 \mathrm{~cm}$ height) were inserted to a depth of $8-9 \mathrm{~cm}$ into the soil. Within each plot, two bases were installed between maize rows a few days after planting. Temporally, the bases were removed to allow some field activities (application of herbicide or fertilizer) and later reinserted in the same location. The polyvinyl chloride cap had a vent tube and rubber stopper used as a port for air sample withdrawal. Gas samplings were generally made between 10:00 and $12: 00 \mathrm{~h}$ to minimize the diurnal variation in the flux rates (Parkin and Venterea, 2010). Caps were placed over the bases immediately before gas sampling, and gas samples of $10 \mathrm{~mL}$ were taken at regular intervals $(0,15$ and $30 \mathrm{~min}$.) from the chamber headspace through the septum by inserting a syringe. Immediately, gas samples were transferred into evacuated $6 \mathrm{~mL}$ glass vials and kept at room temperature until chromatographic analysis. The gas chromatograph (Shimadzu GC 2014 model "Greenhouse") used to quantified the gas concentration was equipped with an automatic sample injection system at $250{ }^{\circ} \mathrm{C}$, a column at $70{ }^{\circ} \mathrm{C}$, a ${ }^{63} \mathrm{Ni}$ electron capture detector set at $350{ }^{\circ} \mathrm{C}$ for $\mathrm{N}_{2} \mathrm{O}$. The $\mathrm{N}_{2}$ was the carrier gas, flowing at $30 \mathrm{~mL} \mathrm{~min}^{-1}$.

Concentrations of $\mathrm{N}_{2} \mathrm{O}$ obtained by gas chromatograph were converted to mass units using the ideal gas law:

$\mathrm{PV}=\mathrm{nRT}$

Where $\mathrm{P}$ is atmospheric pressure (atm), $\mathrm{V}$ is the gas volumen $(\mathrm{L}), \mathrm{n}$ is the number of moles of the gas, $\mathrm{R}$ is the universal gas constant $\left(0.0821 \mathrm{~L} \mathrm{~atm} \mathrm{~mol}^{-1} \mathrm{~K}^{-1}\right)$ and $\mathrm{T}$ is air temperature in ${ }^{\circ} \mathrm{K}$. The daily $\mathrm{N}_{2} \mathrm{O}$ fluxes were calculated from the rate of change of gas concentration as a function of three consecutive measurements over the sampling time, using the method proposed by Venterea (2010) with linear regression. This method was designed to calculate the magnitude of underestimation of flux due to suppression of gas concentration gradient at the soil surface after chamber closure, and in order to correct this effect, it uses correction factors which takes into consideration some specific soil conditions and chamber characteristics (Venterea et al., 2011).

Cumulative $\mathrm{N}_{2} \mathrm{O}$ emissions ( $\mathrm{g} \mathrm{N}_{2} \mathrm{O}-\mathrm{N} \mathrm{ha}^{-1}$ ) were estimated by linear interpolation and integration of fluxes measured daily. Cumulative $\mathrm{N}_{2} \mathrm{O}$ emissions correspond to the total emissions calculated over 153 days in the 2011-12 season and 156 days in the 2012-13 season. Cumulative yield-scaled $\mathrm{N}_{2} \mathrm{O}$ emissions ( $\mathrm{g} \mathrm{N}_{2} \mathrm{O}-\mathrm{N} \mathrm{kg}^{-1}$ grain) were calculated by dividing cumulative $\mathrm{N}_{2} \mathrm{O}$ emissions by the corresponding grain yield $\left(\mathrm{Mg}\right.$ grain $\left.\mathrm{ha}^{-1}\right)$.

\subsection{Soil and weather variables}

At each time of gas sampling, composite soil samples were obtained from each plot by taking about 15 cores $(2.5 \mathrm{~cm}$ diameter) to a depth of 0 to $10 \mathrm{~cm}$, near the chambers. Soil samples were placed in sealed plastic bags, returned to laboratory, and homogenized. Subsamples were weighed for gravimetric water content determination by oven drying at $105{ }^{\circ} \mathrm{C}$ for $24 \mathrm{~h}$, and the remaining field moist soil was used to determine the concentration of nitrate- $\mathrm{N}\left(\mathrm{NO}_{3}^{-}-\mathrm{N}\right)$. $\mathrm{NO}_{3}^{-}-\mathrm{N}$ analyses were performed by extracting $20 \mathrm{~g}$ of soil with $100 \mathrm{~mL}$ of $\mathrm{KCl}\left(1 \mathrm{~mol} \mathrm{~L}^{-1}\right)$ and shaking for $60 \mathrm{~min}$ at 250 revolutions $\mathrm{min}^{-1}$. Extracts were filtered through Whatman $n^{\circ} .42$ filter paper and then analyzed following the procedure described by Keeney and Nelson (1982). $\mathrm{NO}_{3}^{-}-\mathrm{N}$ values are expressed on a dry soil basis.

Soil bulk density was determined in the $0-10 \mathrm{~cm}$ soil layer by using the core method described by Blake and Hartge (1986). Soil gravimetric water content and bulk density values were used to calculate WFPS, expressed as percent, using the following equation:

WFPS $(\%)=(\theta / p) \times 100$

where $\theta$ is volumetric soil water content and $p$ is soil porosity, and $p$ was calculated as:

$p=1-($ dry bulk density/soil particle density $)$

where soil particle density of $2.65 \mathrm{Mg} \mathrm{m}^{-3}$ was assumed.

Simultaneously, at the time of each flux measurement and soil sampling, soil temperature was recorded by using a digital thermometer inserted to a depth of $10 \mathrm{~cm}$ and located very close to the chamber. 
Daily precipitation and air temperature data were obtained from the meteorological station located at the Research Station, approximately $500 \mathrm{~m}$ away from the field experiment.

\subsection{Grain yield}

When crops reached physiological maturity, maize ears were manually harvested from the middle two rows of each plot. Ears were air dried, shelled, and further dried for 3 days at $65^{\circ} \mathrm{C}$ and weighed to obtain dry grain yields.

\subsection{Statistical analysis}

Prior to statistical analysis, data were tested for homogeneity of variance and normality, and transformed when necessary. Soil $\mathrm{N}_{2} \mathrm{O}$ fluxes and $\mathrm{NO}_{3}^{-}-\mathrm{N}$ concentrations were log-transformed because the original data were non-normally distributed. Soil $\mathrm{N}_{2} \mathrm{O}$ fluxes and edaphic variables were analyzed for the 2011-12 season separately from the 2012-13 season, while cumulative $\mathrm{N}_{2} \mathrm{O}$ emissions, yields, yield-scaled $\mathrm{N}_{2} \mathrm{O}$ emissions and fertilizer-induced $\mathrm{N}_{2} \mathrm{O}$ emissions were pooled together.

Analyses of soil temperature, water content and $\mathrm{NO}_{3}^{-}-\mathrm{N}$ concentration at each sampling time were done by ANOVA, to detect differences between treatments. Autocorrelation analysis of $\mathrm{N}_{2} \mathrm{O}$ fluxes measured in individual plots with time was not significant, therefore no attempt was made to combine the analysis of dates within a year using a mixed model ANOVA with dates as repeated measures to statistically examine the response with time. Pearson correlation coefficients were determined to analyze the relation between soil $\mathrm{N}_{2} \mathrm{O}$ fluxes and soil variables. Statistical significance was evaluated at $p<0.05$. All statistical analyses were performed using R software (R Core Team, 2016).

\section{Results}

\subsection{Air temperature and precipitation}

In the two growing seasons, daily air temperature showed a dynamic similar to historical records (Fig. 1; Table 2). During the gas measurement period, the mean daily air temperature was $1{ }^{\circ} \mathrm{C}$ warmer $\left(19.8{ }^{\circ} \mathrm{C}\right)$ in $2011-12$ compared with that registered $\left(18.9{ }^{\circ} \mathrm{C}\right)$ in 2012-13. In both seasons, the mean air temperature was slightly higher than the 30 -yr average of $17.5^{\circ} \mathrm{C}(1980-2010)$.

Precipitation and frequency of rainfall events per month varied between the two maize growing seasons (Fig. 1, Table 2). This first season (2011-12, 153 days), was characterized by a drought stress on late December-mid January, around maize silking stage. During the gas measurement period, total precipitation was $416 \mathrm{~mm}$. Rainfall events occurred on 29 different days of which 15 days never exceeded $10 \mathrm{~mm}$ of daily rainfall, 11 days recorded daily rains between 10 and $30 \mathrm{~mm}$, and 3 days had daily precipitation between 45 and $65 \mathrm{~mm}$.

In the second season (2012-13,156 days), total precipitation was $649 \mathrm{~mm}$ and rainfall events were more frequent, recording 38 days with precipitation. There were 9 days with precipitation above $25 \mathrm{~mm}$ of which 7 days were between 33 and $88 \mathrm{~mm}, 8$ days had total daily
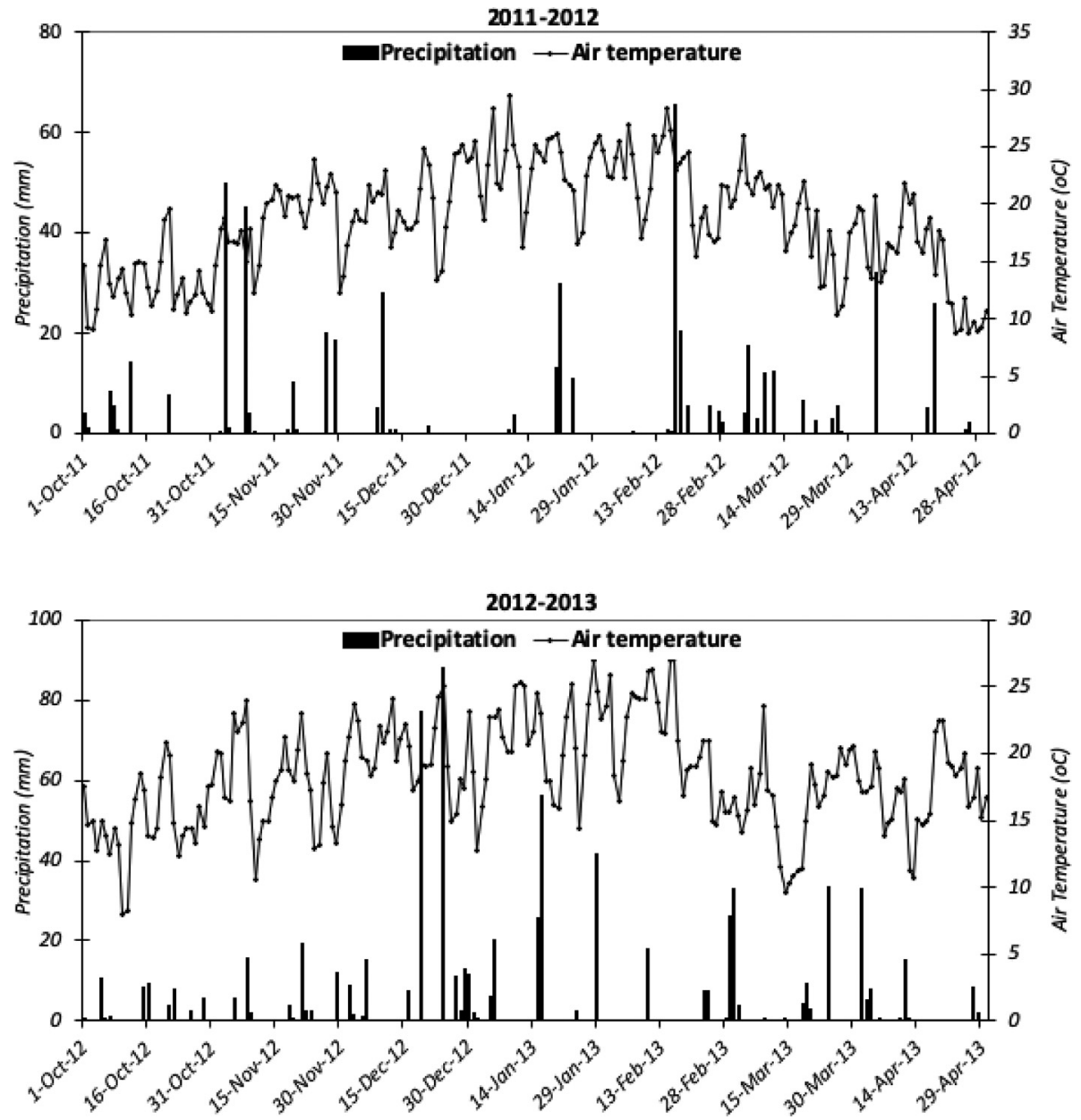

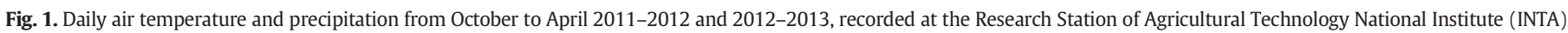
Balcarce, Argentina. 
Table 2

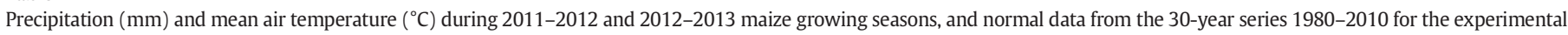
site.

\begin{tabular}{|c|c|c|c|c|c|c|}
\hline \multirow[t]{2}{*}{ Month } & \multicolumn{3}{|c|}{ Precipitation (mm) } & \multicolumn{3}{|c|}{ Air temperature $\left({ }^{\circ} \mathrm{C}\right)$} \\
\hline & 2011-2012 & 2012-2013 & $1980-2010$ & 2011-2012 & 2012-2013 & $1980-2010$ \\
\hline October & 41 & 51 & 93 & 13.0 & 14.9 & 13.5 \\
\hline November & 151 & 64 & 92 & 18.7 & 17.8 & 16.2 \\
\hline December & 36 & 239 & 99 & 19.9 & 20.2 & 18.9 \\
\hline January & 58 & 152 & 111 & 23.2 & 21.1 & 20.8 \\
\hline February & 105 & 33 & 84 & 22.0 & 21.1 & 20.0 \\
\hline March & 67 & 114 & 95 & 18.7 & 16.4 & 18.3 \\
\hline April & 66 & 74 & 85 & 14.7 & 17.2 & 14.6 \\
\hline Total & 523 & 726 & 659 & & & \\
\hline
\end{tabular}

rainfalls between 10 and $25 \mathrm{~mm}$, and the rest of daily rains were below $10 \mathrm{~mm}$. Total precipitation during October through April, was $136 \mathrm{~mm}$ lower in 2011-12 (523 mm) than the 30-year mean of $659 \mathrm{~mm}$, but in 2012-13 (726 mm) it was $67 \mathrm{~mm}$ above the 30-yr average (Table 2).

\subsection{Soil temperature, water content, and nitrate concentration}

In 2011-12, neither soil temperature nor water content were significantly $(p>0.05)$ affected by the management system, however there were significant differences $(p<0.05)$ in both variables between sampling dates. Soil temperature gradually increased from around $17{ }^{\circ} \mathrm{C}$ on 2 November 2011 to $26^{\circ} \mathrm{C}$ on 29 December 2011 but at the end of January 2012 decreased to $21^{\circ} \mathrm{C}$. It again increased during February 2012 , declined to $18{ }^{\circ} \mathrm{C}$ at the end of this month and stayed relatively constant for the rest of the study period (Fig. 2a). Soil water content reached peaks of $0.25,0.27$ and $0.24 \mathrm{~g} \mathrm{~g}^{-1}$ on 10 November 2011, and 1 and 13 December 2011; respectively, as a result of rainfall events that occurred days before (Fig. 3a). During the next 57-day period (20 December 2011-15 February 2012), water content decreased to reach a value of $0.08 \mathrm{~g} \mathrm{~g}^{-1}$, except on 26 January 2012 when increased to $0.19 \mathrm{~g} \mathrm{~g}^{-1}$ due to previous precipitation of $50 \mathrm{~mm}$. At the end of February 2012 and during March 2012, soil water content increased to about $0.25-0.28 \mathrm{~g} \mathrm{~g}^{-1}$ in response to late-season rainfalls and remained stable by early April 2012. The highest moisture contents recorded on 10 November 2011, 1 December 2011, 20 and 29 February 2012, and 14 March 2012 were not different $(p>0.05)$ from those recorded after physiological maturity, 15 March 2012.

In 2012-13, there were significant $(p<0.05)$ differences in soil temperature and moisture due to management system and sampling date. Soil temperature and water content were greater $(p<0.05)$ in FP than in EI, but the difference between the two treatments was very small $\left(0.25^{\circ} \mathrm{C}\right.$ and $\left.0.006 \mathrm{~g} \mathrm{~g}^{-1}\right)$ for both variables. Soil temperature increased from around $16{ }^{\circ} \mathrm{C}$ at the end of October 2012 to $21^{\circ} \mathrm{C}$ at the middle of December 2012 . Then, it decreased to $16{ }^{\circ} \mathrm{C}$ during the last week of December and first week of January 2013 and gradually increased to $23^{\circ} \mathrm{C}$ in the middle of February 2013. Finally, soil temperature decreased to the initial value in the first days of April 2013 (Fig. 2b). With regard to soil water content, after decreasing from $0.27 \mathrm{~g} \mathrm{~g}^{-1}$ to $0.22 \mathrm{~g} \mathrm{~g}^{-1}$ on 7 November 2012, it increased to $0.28 \mathrm{~g} \mathrm{~g}^{-1}$ at the end of November 2012 and beginning of December 2012, but declined to about $0.17 \mathrm{~g} \mathrm{~g}^{-1}$ during the next days in December. Soil water content peaked, following rainfall events. Mean soil water content was higher in the 2012-13 season (average $0.23 \mathrm{~g} \mathrm{~g}^{-1}$, range $0.16-0.32 \mathrm{~g} \mathrm{~g}^{-1}$ ) than in the 2011-12 season (average $0.19 \mathrm{~g} \mathrm{~g}^{-1}$, range $0.07-0.28 \mathrm{~g} \mathrm{~g}^{-1}$ ), with the greatest differences being observed during middle December to middle February period, when severe drought was recorded in 2011-12.

The WFPS followed a pattern similar to that of soil water content and rainfall event (data not shown). Treatment-average WFPS ranged from $13 \%$ to $52 \%$, with most of the values being between $13 \%$ and $40 \%$, in the 2011-12 season. Meanwhile, in the 2012-13 season, treatment-average
WFPS varied from $31 \%$ to $60 \%$, with most of the values between $40 \%$ and $60 \%$, but only one date showing a WFPS of $60 \%$.

Analysis of variance indicated that soil $\mathrm{NO}_{3}^{-}-\mathrm{N}$ concentrations in the upper $10 \mathrm{~cm}$ were significantly $(p<0.05)$ affected by the interaction management system $\times$ sampling date in both growing seasons. In general, $\mathrm{NO}_{3}-\mathrm{N}$ availability increased during November or December, depending on the treatment, as a result of $\mathrm{N}$ fertilizer applications and organic $\mathrm{N}$ mineralization from soil and residues of the previous crop, and decreased along the maize cycle because of plant uptake (Fig. 4a and b).

\subsection{Soil nitrous oxide fluxes and cumulative emissions}

Soil $\mathrm{N}_{2} \mathrm{O}$ fluxes ranged between 3 and $97 \mu \mathrm{N} \mathrm{N}_{2} \mathrm{O}-\mathrm{N} \mathrm{m}^{-2} \mathrm{~h}^{-1}$, and were significantly $(p<0.05)$ affected by management system $\times$ sampling date interaction, in both growing seasons (Fig. 5). Peaks of $\mathrm{N}_{2} \mathrm{O}$ flux were observed following precipitations events and/or $\mathrm{N}$ fertilizer applications in both seasons, i.e. November 2011 for FP and December 2011 for EI, and late February 2012 for both systems on 2011-12; and late November 2012, late December 2012, and late January 2013 for EI and FP on 2012-13. There were significant $(p<0.05)$ differences between management systems in sampling dates following fertilizer applications coupled with rainfall events, on 10 November 2011, 1 and 6 December 2011, 14 November 2012, and March 2013. For the rest of the measurement periods, $\mathrm{N}_{2} \mathrm{O}$ fluxes remained very low, in general without differences between both managements.

There were no significant $(p>0.05)$ effects of management system or season, and management system $\times$ season interaction on cumulative $\mathrm{N}_{2} \mathrm{O}$ emissions. Averaged across the two managements, total $\mathrm{N}_{2} \mathrm{O}$ emissions were $508 \mathrm{~g} \mathrm{~N}_{2} \mathrm{O}-\mathrm{N} \mathrm{ha}^{-1}$ during 153 days in 2011-12 compared with $628 \mathrm{~g} \mathrm{~N}_{2} \mathrm{O}-\mathrm{N} \mathrm{ha}^{-1}$ during the period time of 156 days in 2012-13. Cumulative $\mathrm{N}_{2} \mathrm{O}$ emissions in EI averaged across the two seasons were $558 \mathrm{~g} \mathrm{~N}_{2} \mathrm{O}-\mathrm{N} \mathrm{ha}^{-1}$ relative to $578 \mathrm{~g} \mathrm{~N}_{2} \mathrm{O}-\mathrm{N} \mathrm{ha}^{-1}$ in FP.

The result of two-way ANOVA shows that significant management system $\times$ season interaction was found for grain yield. Grain yield in EI was higher than under FP in 2011-12 $(p<0.05)$, but there were no differences in the 2012-13 season (Table 3). Cumulative $\mathrm{N}_{2} \mathrm{O}$ emissions expressed per unit grain yield, were only affected by management system $(p<0.05)$ (Table 3). The FP treatment had higher emissions based on yield than the EI treatment, yield-scaled $\mathrm{N}_{2} \mathrm{O}$ emissions were of 75-77 $\mathrm{g} \mathrm{N}_{2} \mathrm{O}-\mathrm{N} \mathrm{Mg}$ yield $^{-1}$ for EI and 85-115 $\mathrm{g} \mathrm{N}_{2} \mathrm{O}-\mathrm{N} \mathrm{Mg}$ yield ${ }^{-1}$ for FP.

The relationship between $\mathrm{N}_{2} \mathrm{O}$ fluxes and some soil variables are shown in Table 4. Positive and significant relationships between $\mathrm{N}_{2} \mathrm{O}$ flux and $\mathrm{NO}_{3}^{-}-\mathrm{N}$ concentration and water content were found for both managements in the two seasons. Concentrations of $\mathrm{NO}_{3}^{-}-\mathrm{N}$ were more highly correlated (positively) with $\mathrm{N}_{2} \mathrm{O}$ fluxes in the FP treatment $(r=0.67)$ compared to the EI treatment $(r=0.40)$ in 2011-12, while in 2012-13 the correlation between both variables was lower but significant in the two treatments ( $r=0.30$ for $\mathrm{CM} ; r=0.35$ for IM). However, water content was most strongly related to $\mathrm{N}_{2} \mathrm{O}$ fluxes in both management systems ( $r=0.58$ for $\mathrm{CM} ; r=0.55$ for IM) in 2012-13. Fluxes of 

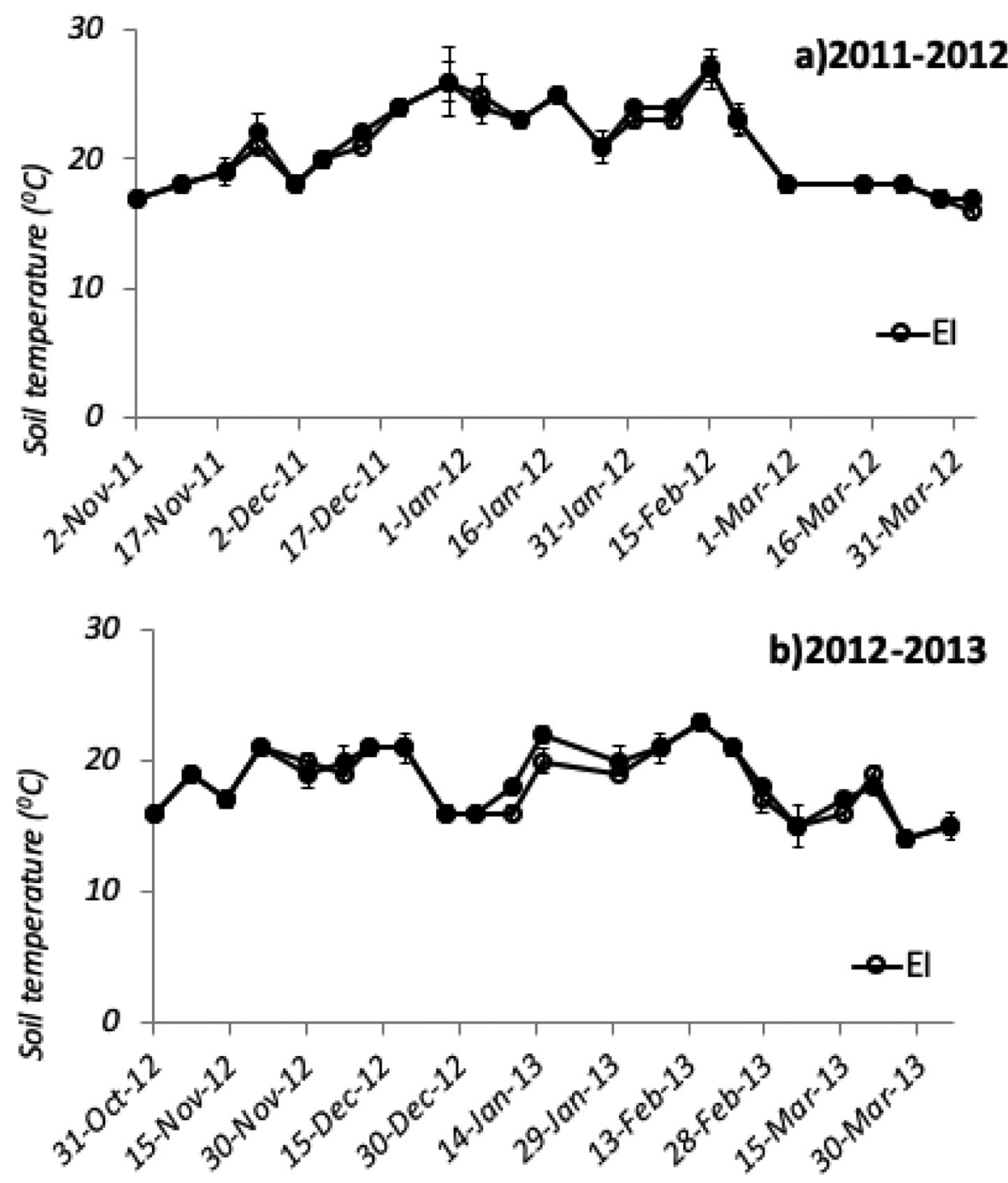

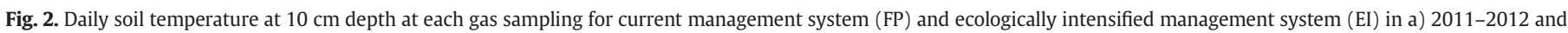
b) 2012-2013 maize growing seasons. Vertical bars represent the standard deviation and those not shown were smaller than the symbols.

$\mathrm{N}_{2} \mathrm{O}$, on the other hand, were positively correlated with soil temperature only in the FP treatment during the 2011-12 season.

\section{Discussion}

The dynamics of $\mathrm{N}_{2} \mathrm{O}$ fluxes during the maize growing season exhibited pronounced fluctuations in both management systems. These $\mathrm{N}_{2} \mathrm{O}$ fluxes are in the same range as those observed by Venterea et al. (2016) over two maize growing seasons in Minnesota (1-140 $\mu \mathrm{g} \mathrm{N}_{2} \mathrm{O}-$ $\mathrm{N} \mathrm{m}^{-2} \mathrm{~h}^{-1}$ ). The highest $\mathrm{N}_{2} \mathrm{O}$ fluxes took place during relatively brief periods and following applications of $\mathrm{N}$ fertilizer in the wettest months, mid-late spring and early summer, and even when soil temperature was relatively low $\left(<20^{\circ} \mathrm{C}\right)$ as in $2011-12$ and $\mathrm{NO}_{3}^{-}-\mathrm{N}$ concentration was around $5 \mathrm{mg} \mathrm{NO}-\mathrm{N}_{3}^{-}-\mathrm{Ng}^{-1}$ as in 2012-13. These results agree with those reported in several studies that have shown highest $\mathrm{N}_{2} \mathrm{O}$ fluxes during late spring and early summer, in response to rainfall events after $\mathrm{N}$ fertilizer was applied (Parkin and Kaspar, 2006; Omonode et al., 2010; Venterea et al., 2011; Della Chiesa et al., 2019). Also, soil drying-rewetting events can induce $\mathrm{N}_{2} \mathrm{O}$ emission pulses (Beare et al., 2009; Pelster et al., 2011; Guo et al., 2014), because they produce disruption of soil microstructure (Reatto et al., 2009), and release of previously inaccessible substrates for use by microbes. Soil rewetting probably explains the peaks observed after a dry period, for example late in the maize cycle on 20 February 2012 when soil water content increased from 0.08 to $0.25 \mathrm{~g} \mathrm{~g}^{-1}$, after heavy rainfall.

The peaks of $\mathrm{N}_{2} \mathrm{O}$ emissions can make an important contribution to total $\mathrm{N}_{2} \mathrm{O}$ emissions (Jacinthe and Dick, 1997; Parkin and Kaspar, 2006). In 2011-12, $31 \%$ of the cumulative $\mathrm{N}_{2} \mathrm{O}$ emission was due to the two peaks that occurred on 10 November and 13 December 2011, while in 2012-13, the peaks that covered a period of 27 days from 30 November and 27 December 2012 accounted for $29 \%$ of the total $\mathrm{N}_{2} \mathrm{O}$ emissions. Similarly, Parkin and Kaspar (2006) reported that $45 \%$ and $49 \%$ of the cumulative $\mathrm{N}_{2} \mathrm{O}$ flux in plots under maize was due to two peaks which occurred at 29 and 14 days apart; respectively. In Australia in a cropped soil, 75 to $85 \%$ of the annual fluxes were attributed to peaks due to isolated and summer rainfall events (Barton et al., 2013). Therefore, if peaks of $\mathrm{N}_{2} \mathrm{O}$ fluxes are not captured, in particular following $\mathrm{N}$ fertilizer applications, irrigation/rains, and soil rewetting or spring-thaw events, the total $\mathrm{N}_{2} \mathrm{O}$ emissions calculated from field measurements are underestimated (Parkin and Kaspar, 2006; Barton et al., 2015) causing uncertainties in the global $\mathrm{N}_{2} \mathrm{O}$ budgets.

Since soil moisture content is a determinant factor of soil $\mathrm{N}_{2} \mathrm{O}$ emission as it regulates the oxygen availability to soil microorganisms (Linn and Doran, 1984; Butterbach-Bahl et al., 2013), which carry out denitrification and/or nitrification process, the effect of $\mathrm{N}$ fertilizer depends if 

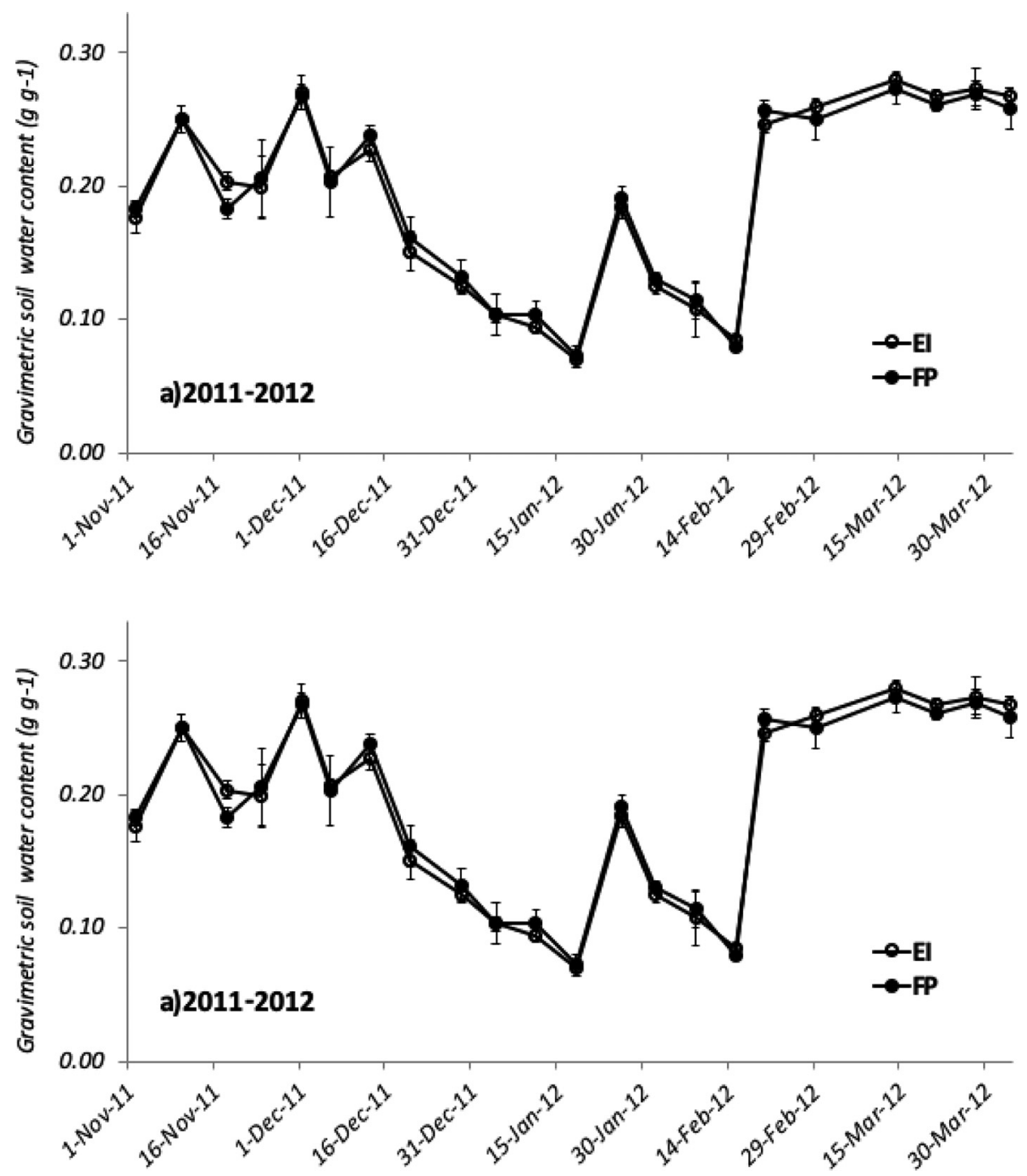

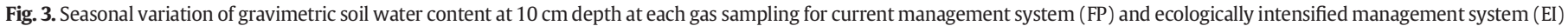
in a) 2011-2012 and b) 2012-2013 maize growing seasons. Vertical bars represent the standard deviation and those not shown were smaller than the symbols.

its application time matches with timing and quantity of rainfall. In the 2011-12 season, $\mathrm{N}_{2} \mathrm{O}$ fluxes began to be monitored on 2 November 2011, 15 days after applying 14 and $13 \mathrm{~kg} \mathrm{~N} \mathrm{ha}^{-1}$ as DAP in EI and FP, respectively, but before the application of high rates of $\mathrm{N}$ in both treatments ( $46 \mathrm{~kg} \mathrm{~N} \mathrm{ha}^{-1}$ as UAN in EI and $37 \mathrm{~kg} \mathrm{~N} \mathrm{ha}^{-1}$ as urea in FP). However, the low precipitation (one rain event of $7.5 \mathrm{~mm}$ and another of $0.4 \mathrm{~mm}$ ) recorded over the mentioned period probably did not affect $\mathrm{N}_{2} \mathrm{O}$ fluxes. In fact, at the first sampling date, soil water content was relatively low, $0.18 \mathrm{~g} \mathrm{~g}^{-1}$. In the $2012-13$ season, $\mathrm{N}_{2} \mathrm{O}$ emissions began to be measured on 31 October 2012, about 13 days after whole rate of $\mathrm{N}$ fertilizer (as DAP + urea) was applied in FP. During that period of time, sporadic and low intensity rains $(<8 \mathrm{~mm})$ were registered with a total precipitation of $20 \mathrm{~mm}$, therefore it was not expected a major effect of rainfall on $\mathrm{N}_{2} \mathrm{O}$ emissions. If the temporal variability of $\mathrm{N}_{2} \mathrm{O}$ fluxes is not considered, the precision of cumulative $\mathrm{N}_{2} \mathrm{O}$ emissions calculated from field measurements with soil chambers would be affected (Parkin, 2008).

The optimum level of WFPS for $\mathrm{N}_{2} \mathrm{O}$ emissions was suggested to be in the range $70-80 \%$, depending on soil type (Davidson et al., 2000). However, Bateman and Baggs (2005) demonstrated that autotrophic nitrification was the predominant process contributing to $\mathrm{N}_{2} \mathrm{O}$ production at WFPS values between $35 \%$ and $60 \%$ while denitrification process accounted for $100 \%$ of the $\mathrm{N}_{2} \mathrm{O}$ emitted at $70 \%$ of WFPS. In our study,
WFPS largely remained below 40\% 2011-12, while in 2012-13 most of daily $\mathrm{N}_{2} \mathrm{O}$ fluxes occurred between $40 \%$ and $60 \%$ of WFPS. As a reference, WFPS values of $40 \%$ and $60 \%$ correspond to soil water contents that are below and close, respectively, to field capacity for a Typic Argiudol in agricultural soils of the region (Falasca and Ulberich, 2006). Then, considering that in our experiment WFPS never exceeded 60\% even after heavy rainfall, nitrification is thought to be the major process responsible of $\mathrm{N}_{2} \mathrm{O}$ emissions. In a field study conducted under optimal drainage, where WFPS frequently remained below $40 \%$, nitrification process was suggested as main responsible for low emissions of $\mathrm{N}_{2} \mathrm{O}$ (Jantalia et al., 2008). Similarly, Skiba et al. (1994) observed that $\mathrm{N}_{2} \mathrm{O}$ was produced predominantly by nitrification process when soil was dry in contrast to denitrification process that was the dominant source of $\mathrm{N}_{2} \mathrm{O}$ under wet soil conditions.

Although correlations between $\mathrm{N}_{2} \mathrm{O}$ fluxes and soil factors were somewhat low, their functional relationship and effects on fluxes were highly significant in most cases $(p<0.001)$. The multiple interactions among factors that control the production and consumption processes of gases, and the delay between production and emission of gases (Wagner-Riddle et al., 2008), usually result in poor or no correlations between soil properties ( $\mathrm{N}$ content, water content and temperature) and $\mathrm{N}_{2} \mathrm{O}$ fluxes (Rochette et al., 2004). In addition, each individual factor explains part of the variation of the gas emission. The correlation 

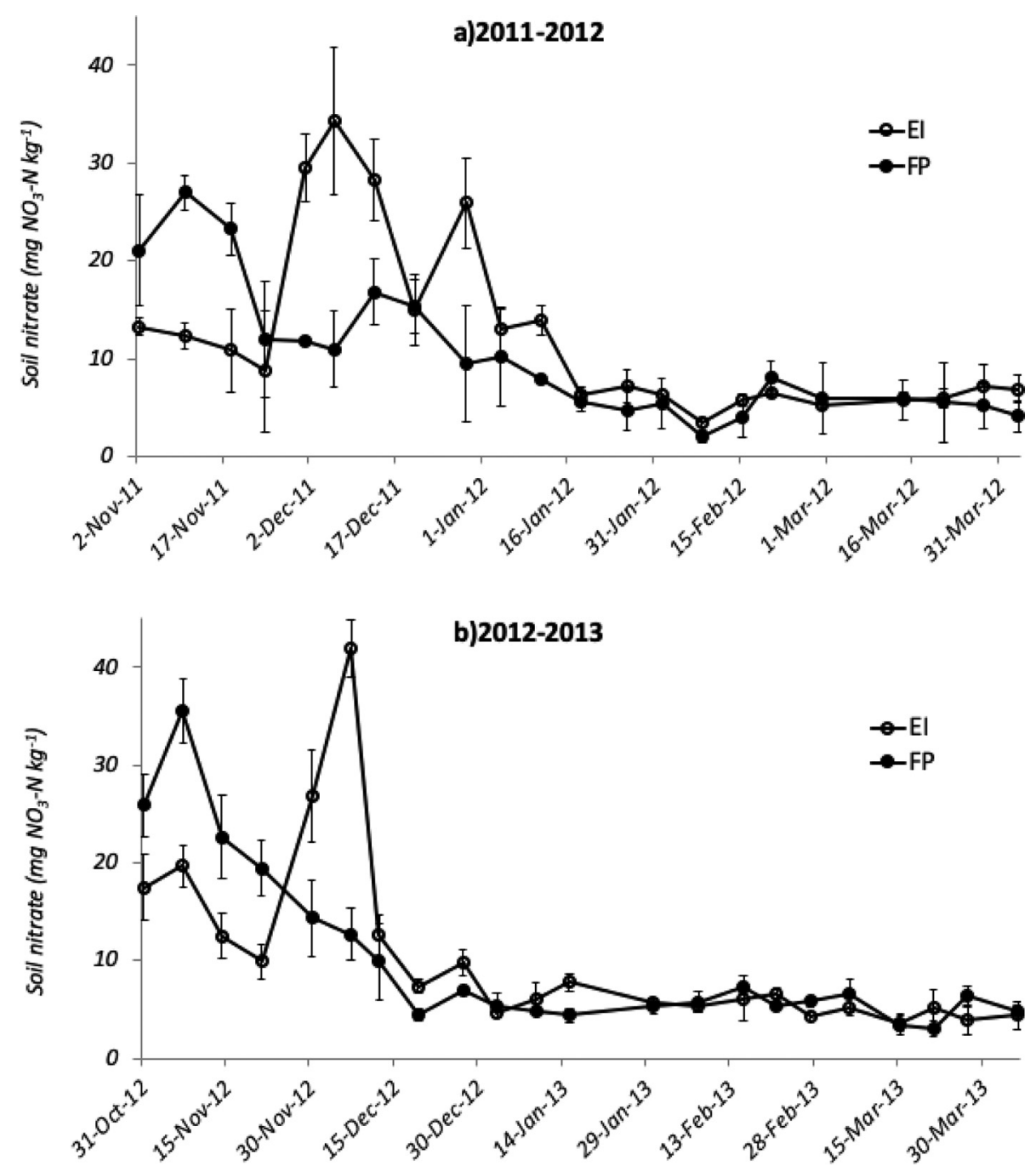

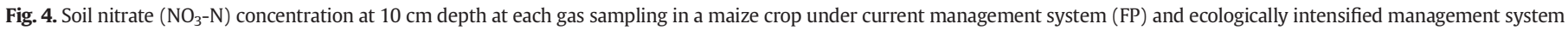
(EI) during a) 2011-2012, and b) 2012-2013 growing seasons. Vertical bars represent the standard deviations and those not shown were smaller than the symbols.

between $\mathrm{N}_{2} \mathrm{O}$ flux and $\mathrm{NO}_{3}^{-}-\mathrm{N}$ concentration was stronger for FP compared to EI in the 2011-12 season, while water content was best correlated to $\mathrm{N}_{2} \mathrm{O}$ flux under both managements during the 2012-13 season. These relationships can be expected since $\mathrm{NO}_{3}^{-}$is required for $\mathrm{N}_{2} \mathrm{O}$ production generated via nitrification-coupled denitrification and heterotrophic denitrification, and water content regulates the oxygen concentration which affects the activity of nitrifier and denitrifier microorganisms (Bateman and Baggs, 2005). Fluxes of $\mathrm{N}_{2} \mathrm{O}$ were correlated to soil temperature but only in the FP treatment. Temperature is also an important driver of both, nitrification and denitrification in soils (Voroney and Heck, 2015; Cosentino et al., 2013), because it influences microbial kinetics that mediates the mentioned processes, and soil respiration which in turn can affect oxygen availability.

Management system did not significantly $(p>0.05)$ affect cumulative soil $\mathrm{N}_{2} \mathrm{O}$ emissions, which were on average 558 and $578 \mathrm{~g} \mathrm{~N}_{2} \mathrm{O}-\mathrm{N} \mathrm{ha}^{-1}$ for $\mathrm{EI}$ and $\mathrm{FP}$, respectively, although EI received a higher $\mathrm{N}$ rate. In general, it has been reported that $\mathrm{N}_{2} \mathrm{O}$ emissions increase with increasing $\mathrm{N}$ fertilizer application rates, especially when $\mathrm{N}$ is applied above crop requirements (Eagle et al., 2017; Han et al., 2017; Omonode et al., 2017; Zhao et al., 2017). However, in our study, the different fertilization strategies ( $N$ source and timing of application), plus improved crop management practices, would have contributed to reducing $\mathrm{N}_{2} \mathrm{O}$ losses in EI compared to FP despite the higher rate of $\mathrm{N}$. Furthermore, for these experiments, Caviglia et al. (2019) reported an increase in the $\mathrm{N}$ utilization efficiency by applying a target set of agronomic practices, which included an increase in the $\mathrm{N}$ rate in El. Thus, increases in $\mathrm{N}$ rates without exceeding crop $\mathrm{N}$ requirements in a medium-input system would allow to improve $\mathrm{N}$ use efficiency and avoid significant $\mathrm{N}_{2} \mathrm{O}-\mathrm{N}$ losses (Van Groenigen et al., 2010; Caviglia et al., 2019).

Similar to this study, where the difference in $\mathrm{N}$ rate between the two treatments was small (20\%), Venterea et al. (2016) did not find differences in area scaled- $\mathrm{N}_{2} \mathrm{O}$ emissions when urea was single and split applied at $100 \%$ of the recommended $\mathrm{N}$ rate compared to split urea application at $85 \%$ of the recommended $\mathrm{N}$ rate during the maize growing seasons.

There was also no significant season effect on total $\mathrm{N}_{2} \mathrm{O}$ emissions but they tended to be 20\% greater over 153 days in 2012-13 (average of $627 \mathrm{~g} \mathrm{~N}_{2} \mathrm{O}-\mathrm{N} \mathrm{ha}^{-1}$ for both systems) than over 156 days in 2011-12 (average of $508 \mathrm{~g} \mathrm{~N}_{2} \mathrm{O}-\mathrm{N} \mathrm{ha}^{-1}$ for both systems). This trend may be partly attributed to differences in total precipitation between both seasons. Total precipitation was lower $(416 \mathrm{~mm})$ and WFPS was generally below $40 \%$ during the time of $\mathrm{N}_{2} \mathrm{O}$ flux sampling in 2011-12, while the higher amount of total precipitation $(649 \mathrm{~mm})$ together with a group of individual rainfall events, some of them very intensive, resulted in WFPS values between $40 \%$ and $60 \%$ during most of the sampling time in 2012-13. Minor differences in soil temperature and $\mathrm{NO}_{3}^{-}-\mathrm{N}$ concentration would also have contributed to differences in cumulative $\mathrm{N}_{2} \mathrm{O}$ emissions between seasons. 


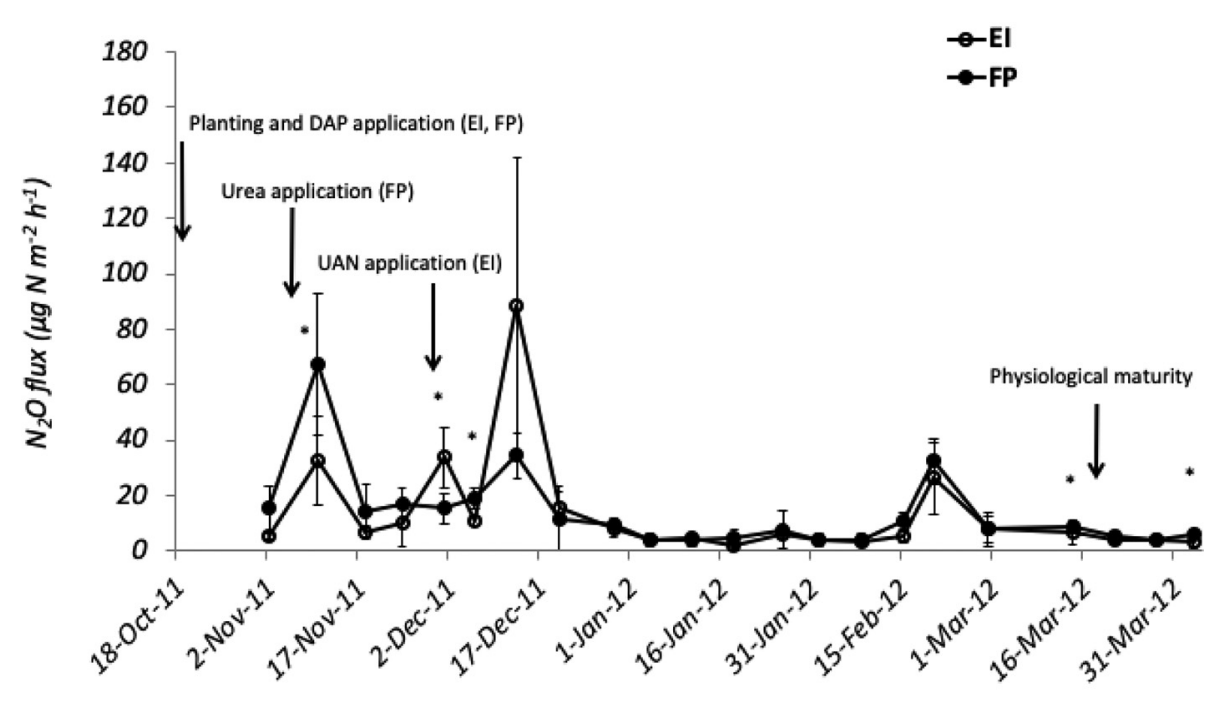

a) 2011-2012

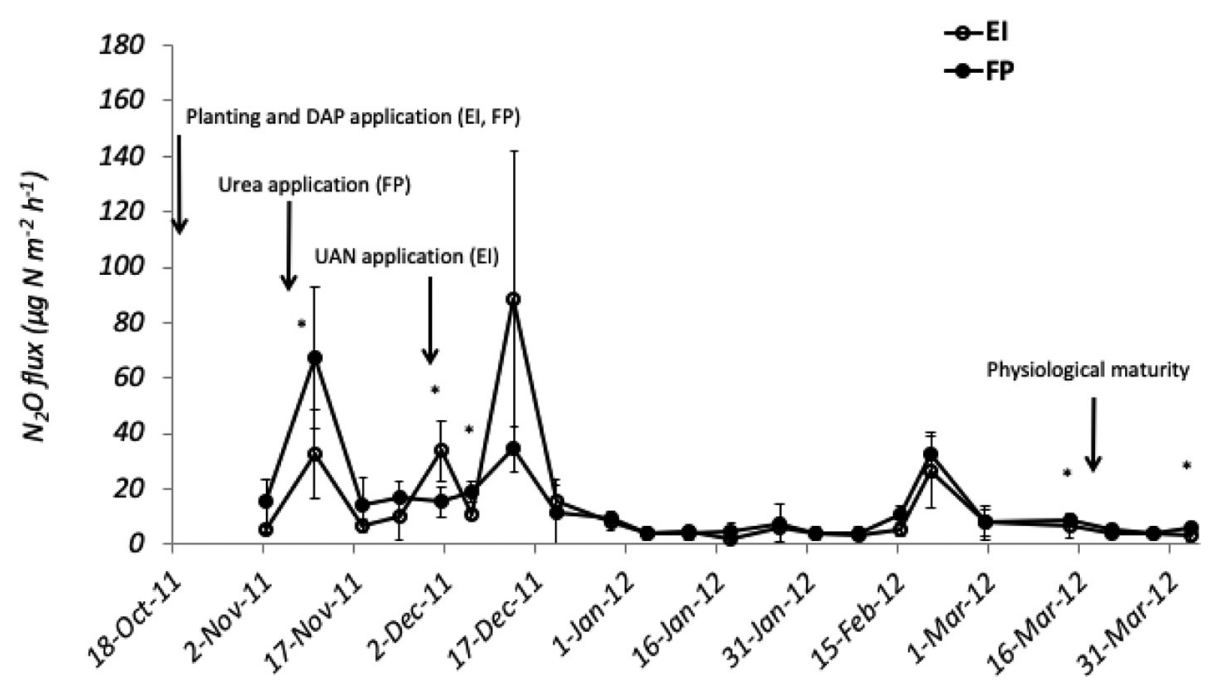

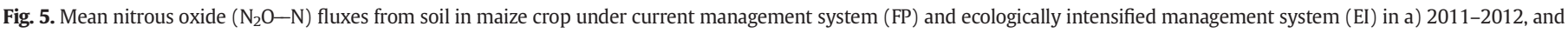
b) 2012-2013 growing seasons. Vertical bars associate with each data point represent the standard deviations and those not shown were smaller than the symbols.

Grain yield was significantly $(p<0.05)$ higher for EI than FP in 2011-12 and showed a similar trend in 2012-13. Thus, integrated crop and nutrient management practices would improve grain yield by improving resource productivity and efficiency (water, radiation and N) (Caviglia et al., 2019). Decreased grain yields in 2011-12 compared to 2012-13 were probably related to greater precipitation during the early vegetative stages (November) and a prolonged dry period that covers late vegetative and early reproductive stages.

Several authors (Van Groenigen et al., 2010; Venterea et al., 2011; Grassini and Cassman, 2012; Burzaco et al., 2013; Maharjan et al., 2014) have suggested to evaluate the impact of management practices on the environment, expressing GHG emissions per unit of grain yield instead of per unit area. According to Van Groenigen et al. (2010), expressing $\mathrm{N}_{2} \mathrm{O}$ emissions in terms of crop productivity is a useful tool to identify the $\mathrm{N}$ rate application that optimizes yields and reduces $\mathrm{N}_{2} \mathrm{O}$ losses per unit of yield.

Yield-based $\mathrm{N}_{2} \mathrm{O}$ emissions in our study (75 to $115 \mathrm{~g} \mathrm{~N}_{2} \mathrm{O}-\mathrm{N} \mathrm{Mg}$ yield $^{-1}$ ) are within the range reported by Venterea et al. (2011) evaluating controlled-release fertilizers and conventional urea in maize under conventional tillage and no-tillage, and by Zhao et al. (2017) for $\mathrm{N}$ rates lower than $171 \mathrm{~kg} \mathrm{~N}^{-1}$ under a broad variety of soils and climate conditions; but higher than those reported by Maharjan et al. (2014) for fully and minimum irrigated maize plots, respectively (30 and $52 \mathrm{~g} \mathrm{~N}_{2} \mathrm{O}-\mathrm{N} \mathrm{Mg}$ yield $^{-1}$ ). In contrast, yield-scaled emissions are lower than those found in other maize studies where yield-scaled $\mathrm{N}_{2} \mathrm{O}-\mathrm{N}$ emissions averaged $1.86 \mathrm{~kg} \mathrm{~N}_{2} \mathrm{O}-\mathrm{N} \mathrm{Mg}$ yield $^{-1}$ for different $\mathrm{N}$ fertilizers and $\mathrm{N}$ rates (Gagnon et al., 2011), or ranged from 167 to $328 \mathrm{~g}$ $\mathrm{N}_{2} \mathrm{O}-\mathrm{N} \mathrm{Mg}$ yield ${ }^{-1}$ for $\mathrm{N}$ rates of 0 to $180 \mathrm{~kg} \mathrm{~N} \mathrm{ha}^{-1}$, respectively (Burzaco et al., 2013).

The EI management system decreased $(p<0.05)$ yield-scaled $\mathrm{N}_{2} \mathrm{O}$ emissions by $24 \%$ compared with the FP management system due to higher grain yield $(+21 \%)$, since there were no significant differences in cumulative $\mathrm{N}_{2} \mathrm{O}$ emissions between both managements. Therefore, these results demonstrate that a moderate increase in $\mathrm{N}$ rate (10 kg N ha ${ }^{-1}$ ), when combined with $\mathrm{N}$ split application and UAN as $\mathrm{N}$ source, as well as other crop management practices (Caviglia et al., 2019; Table 1), might increase grain yield and reduce the yield-scaled $\mathrm{N}_{2} \mathrm{O}$ emissions during maize growing season. Considering the yield- 
Table 3

Cumulative $\mathrm{N}_{2} \mathrm{O}$ emissions, grain yield and grain yield-scaled $\mathrm{N}_{2} \mathrm{O}$ emissions in maize under current management system (FP) and ecologically intensified management system (EI) for season 2011-2012 and 2012-2013.

\begin{tabular}{|c|c|c|c|}
\hline \multirow[t]{2}{*}{ Management } & \multirow{2}{*}{$\begin{array}{l}\text { Cumulative } \mathrm{N}_{2} \mathrm{O} \\
\text { emissions } \\
\mathrm{g} \mathrm{N}_{2} \mathrm{O}-\mathrm{N}\end{array}$} & \multirow{2}{*}{$\begin{array}{l}\text { Grain } \\
\text { yield } \\
\mathrm{Mg} \mathrm{ha}^{-1}\end{array}$} & \multirow{2}{*}{$\begin{array}{l}\text { Yield-scaled } \mathrm{N}_{2} \mathrm{O} \\
\text { emissions } \\
\mathrm{g} \mathrm{N}_{2} \mathrm{O}-\mathrm{N} \mathrm{Mg}^{-1} \text { grain }\end{array}$} \\
\hline & & & \\
\hline \multicolumn{4}{|l|}{ 2011-2012 } \\
\hline EI & 494 & $6.56 \mathrm{~b}$ & $75 \mathrm{~b}$ \\
\hline $\mathrm{FP}$ & 523 & $4.57 \mathrm{c}$ & $115 \mathrm{a}$ \\
\hline \multicolumn{4}{|l|}{$2012-2013$} \\
\hline EI & 622 & $8.12 \mathrm{a}$ & $77 \mathrm{~b}$ \\
\hline \multirow[t]{2}{*}{ FP } & 633 & $7.56 \mathrm{a}$ & $85 \mathrm{a}$ \\
\hline & $p$ value & & \\
\hline Block & 0.521 & 0.922 & 0.526 \\
\hline Season (S) & 0.145 & 0.076 & 0.156 \\
\hline Management (M) & 0.638 & 0.003 & 0.020 \\
\hline $\mathrm{S}^{*} \mathrm{M}$ & 0.832 & 0.024 & 0.063 \\
\hline
\end{tabular}

Grain yield maize at $0 \%$ grain moisture content.

Values within a column followed by different letters are significantly different at $5 \%$ level of significance.

scaled $\mathrm{N}_{2} \mathrm{O}$ emissions, if the same yield were produced under EI and FP, the FP system would emit more $\mathrm{N}_{2} \mathrm{O}$ compared with EI and would require additional land. Thus, our data supports the hypothesis that intensive crop management systems do not necessarily increase GHG emissions per unit of crop or food production, preventing the conversion of natural areas to cropland while meeting global needs for food, fiber, and biofuel (Cassman, 1999; Snyder et al., 2009; Venterea et al., 2016; Zhao et al., 2016).

The experimental design does not allow to estimate fertilizer $\mathrm{N}$ based $\mathrm{N}_{2} \mathrm{O}$ emissions as there were not control plots (no application of $\mathrm{N}$ ). However, even without subtracting cumulative $\mathrm{N}_{2} \mathrm{O}$ emissions from control plots, and thus considering all $\mathrm{N}_{2} \mathrm{O}$ emissions coming from fertilizer $\mathrm{N}$, total $\mathrm{N}_{2} \mathrm{O}-\mathrm{N}$ emissions were below $1 \%$ of the fertilizer $\mathrm{N}$ applied at any of both treatments. This would allow us to suppose that, under conditions of the argentine Pampas, the emission $\mathrm{N}_{2} \mathrm{O}$ factor of fertilizer $\mathrm{N}$ in maize would be lower than the index of $1 \%$ recommended by the IPCC (2007). Studies conducted in the semiarid region of Argentina (Alvarez et al., 2012) and at in southern Brazil (Jantalia et al., 2008) found that $\mathrm{N}_{2} \mathrm{O}$ emissions estimated by integrating fluxes with time, were lower than those calculated by applying the IPCC direct emission factor (Tier $1=1 \%$ ) to the amounts of $\mathrm{N}$ added as fertilizers and returned as crop residues. These data indicate that the IPCCemission factor of $1 \%$ would overestimate true $\mathrm{N}_{2} \mathrm{O}$ emissions from no-tillage cropping systems of southern South America.

Our results indicate that the highest $\mathrm{N}_{2} \mathrm{O}$ fluxes occurred during relatively short periods and following applications of $\mathrm{N}$ fertilizer during the wettest months, mid-late spring and early summer, in both management systems at the two maize growing seasons. Cumulative $\mathrm{N}_{2} \mathrm{O}$

\section{Table 4}

Pearson correlation coefficients between nitrous oxide $\left(\mathrm{N}_{2} \mathrm{O}-\mathrm{N}\right)$ fluxes and soil variables (nitrate $\left(\mathrm{NO}_{3}-\mathrm{N}\right)$ concentration, temperature, water content) during 2011-2012 and 2012-2013 growing seasons.

\begin{tabular}{llll}
\hline & \multicolumn{2}{l}{ Soil properties } & \\
\cline { 2 - 4 } & $\mathrm{NO}_{3}-\mathrm{N}$ & Temperature & Water content \\
\hline $2011-2012$ & & & \\
$\mathrm{EI}$ & $0.40^{* *}$ & $0.21 \mathrm{~ns}$ & $0.40^{* *}$ \\
$\mathrm{FP}$ & $0.67^{* * *}$ & $0.42^{* *}$ & $0.52^{* * *}$ \\
$2012-2013$ & & & \\
$\mathrm{EI}$ & $0.35^{*}$ & $-0.01 \mathrm{~ns}$ & $0.55^{* * *}$ \\
$\mathrm{FP}$ & $0.30^{*}$ & $0.05 \mathrm{~ns}$ & $0.58^{* * *}$ \\
\hline$* ; * * * * *$ & significant at $0.05,0.01$ and 0.001 probability levels, respectively.
\end{tabular}

emissions were not significantly affected by management system. However, when expressed per unit of yield grain, $\mathrm{N}_{2} \mathrm{O}$ emissions decreased in IE compared with FP. The lower yield-scaled $\mathrm{N}_{2} \mathrm{O}$ emissions in IE indicate that intensive systems in this climate regimen might increase crop yield without increasing $\mathrm{N}_{2} \mathrm{O}$ emissions or reducing $\mathrm{N}$ inputs.

The $\mathrm{N}_{2} \mathrm{O}$ emissions were obtained by collecting data only along the maize growing season, without considering differences during the fallow period and/or the presence of another crop in the rotation. Therefore, future research should concentrate on demonstrating the potential impact of such management systems on quantification of annual $\mathrm{N}_{2} \mathrm{O}$ emissions, considering complete rotation.

In conclusion, for current medium-input agroecosystems such as those of maize on mollisols in the Pampas of Argentina (Caviglia et al., 2019), a moderate increase in $\mathrm{N}$ rate $\left(10 \mathrm{~kg} \mathrm{~N} \mathrm{ha}^{-1}\right)$, combined with $\mathrm{N}$ split-application and UAN (urea-ammonium nitrate) as N source, as well as other crop management practices, can be a viable alternative to improve maize productivity without increasing the $\mathrm{N}_{2} \mathrm{O}$ environmental impact.

\section{Declaration of Competing Interest}

None.

\section{Acknowledgments}

This research was supported by the International Plant Nutrition Institute (IPNI), Instituto Nacional de Tecnología Agropecuaria (INTA), Facultad de Ciencias Agrarias.- Universidad Nacional de Mar del Plata (FCA-UNMdP), and Agencia Nacional de Promoción Científica y Tecnológica (ANPCyT PID 2011-0025). We would further like to thank Fertilizar Civil Association and Profertil S.A., for their support and cooperation.

\section{References}

Adviento-Borbe, M.A.A., Haddix, M.L., Binder, D.L., Walters, D.T., Dobermann, A., 2007. Soil greenhouse gas fluxes and global warming potential in four high-yielding maize systems. Glob. Change Biol. 13, 1972-1988.

Alexandratos, N., Bruinsma, J., 2012. World agriculture towards 2030/2050: The 2012 revision. ESA Working paper No.12-03. Food and Agriculture Organization of the United Nations, Rome, Italy, p. 160.

Alvarez, C., Costantini, A., Alvarez, C.R., Alves, B.J.R., Jantalia, C.P., Martellotto, E.E. Urquiaga, S., 2012. Soil nitrous oxide emissions under different management practices in the semiarid region of the Argentinian Pampas. Nutr. Cycl. Agroecosyst. 94, 209-220.

Andrade, F.H., 2016. Los desafíos de la agricultura. 1a ed. International Plant Nutrition Institute, Acassuso, Argentina, p. 136. http://inta.gob.ar/sites/default/files/inta_los_ desafios_de_la_agricultura_fandrade.pdf.

Aramburu Merlos, F., Monzon, J.P., Mercau, J.L., Taboada, M., Andrade, F.H., Hall, A.J., Jobbagy, E., Cassman, K.G., Grassini, P., 2015. Potential for crop production increase in Argentina through closure of existing yield gaps. Field Crops Res. 184, 145-154. https://doi.org/10.1016/j.fcr.2015.10.001.

Barton, L., Murphy, D., Butterbach-Bahl, K., 2013. Influence of crop rotation and liming on greenhouse gas emissions from a semiarid soil. Agric. Ecosyst. Environ. 167, 23-32.

Barton, L., Wolf, B., Rowlings, D., Scheer, C., Kiese, R., Grace, P., Stefanova, K., ButterbachBahl, K., 2015. Sampling frequency affects estimates of annual nitrous oxide fluxes. Sci. Rep. 5 Article Number 15912.

Bateman, E.J., Baggs, E.M., 2005. Contributions of nitrification and denitrification to $\mathrm{N}_{2} \mathrm{O}$ emissions from soils at different water-filled pore space. Biol. Fertil. Soils. 41, 379-388.

Beare, M.H., Gregorich, E.G., St-Georges, P., 2009. Compaction effects on $\mathrm{CO}_{2}$ and $\mathrm{N}_{2} \mathrm{O}$ production during drying and rewetting of soil. Soil Biol. Biochem. 41, 611-621.

Blake, G.H., Hartge, K.H., 1986. Bulk density. In: Klute, A. (Ed.), Methods of Soil Analysis, Part 1: Physical and Mineralogical Methods, 2nd Edition, Agronomy Monograph 9. Soil Science Society of America, American Society of Agronomy, Madison, WI, pp. 363-382.

Burzaco, J.P., Smith, D.R., Vyn, T.J., 2013. Nitrous oxide emissions in Midwest US maize production vary widely with band-injected $\mathrm{N}$ fertilizer rates, timing and nitrapyrin presence. Environ. Res. Lett. 8, 1-11.

Butterbach-Bahl, K., Baggs, E.M., Dannenmann, M., Kliese, R., Zechmeister-Boltenstern, S., 2013. Nitrous oxide emissions from soils: how well do we understand the processes and their controls? Philos. Trans. R. Soc. Lond. B Biol. Sci. 368, 1-13.

Carreno, L., Frank, F.C., Viglizzo, E.F., 2012. Tradeoffs between economic and ecosystem services in Argentina during 50 years of land-use change. Agric. Ecosyst. Environ. $154,68-77$. 
Cassman, K.G., 1999. Ecological intensification of cereal production systems: yield potential, soil quality, and precision agriculture. Proc. Natl. Acad. Sci. USA. 96, 5952-5959.

Cassman, K.G., 2017. Ecological intensification of maize-based cropping systems. Better Crops 101, 4-6. http://www.ipni.net/publication/bettercrops.nsf/0/619D40B5E8D4C2D 585258124006AFEE2/\$FILE/BC-2017-2.pdf.

Caviglia, O.P., Rizzalli, R.H., Monzon, J.P., García, F.O., Melchiori, R.J.M., Martinez, J.J., Cerrudo, A., Irigoyen, A., Barbieri, P.A., Van Opstal, N.V., Andrade, F.H., 2019. Improving resource productivity at a crop sequence level. Field Crops Res. 235, 129-141.

Cosentino, V.R., Figueiro Aureggui, N.S.A., Taboada, M.A., 2013. Hierarchy of factors driving $\mathrm{N}_{2} \mathrm{O}$ emissions in non-tilled soils under different crops. Eur. J. Soil Sci. 64, 550-557.

Davidson, E.A., Keller, M., Erickson, H.E., Verchot, L.V., Veldkamp, E., 2000. Testing a conceptual model of soil emissions of nitrous and nitric oxides. Bioscience. 50, 667-680.

Della Chiesa, T., Piñeiro, G., Yahdjian, L., 2019. Gross, background, and net anthropogenic soil nitrous oxide emissions from soybean, corn, and wheat croplands. J. Environ. Qual. 48, 16-23.

Eagle, A.J., Olander, L.P., Locklier, K.L., Heffernan, J.B., Bernhardt, E.S., 2017. Fertilizer management and environmental factors drive $\mathrm{N}_{2} \mathrm{O}$ and $\mathrm{NO}_{3}$ losses in maize: a metaanalysis. Soil Sci. Soc. Am. J. 81, 1191-1202.

Ernst, O., Kamanian, A., Mazzilli, S., Cadenazzi, M., Dogliotti, S., 2016. Depressed attainable wheat yields under continuous annual no-till agriculture suggest declining soil productivity. Field Crops Res. 186, 107-116.

Falasca, S., Ulberich, A., 2006. El agua disponible de los suelos del sudeste bonaerense, República Argentina. Rev. Geogr. 140, 7-17.

Farquharson, R., Baldock, J., 2008. Concepts in modeling $\mathrm{N}_{2} \mathrm{O}$ emissions from land use. Plant Soil. 309, 147-167.

Foley, J.A., Ramankutty, N., Brauman, K.A., Cassidy, E.S., Gerber, J.S., Johnston, M., Mueller, N.D., Connell, C.O., Ray, D.K., West, P.C., Balzer, C., Bennett, E.M., Carpenter, S.R., Hill, J., Monfreda, C., Polasky, S., Rockstrom, J., Sheeha, J., Sieber, S., Tilman, D., Zaks, D.P.M., 2011. Solutions for a cultivated planet. Nature. 478, 337-342.

Gagnon, B., Ziadi, N., Rochette, P., Chantigny, M.H., Angers, D.A., 2011. Fertilizer source influenced nitrous oxide emissions from a clay soil under maize. Soil Sci. Soc. Am. J. 75, 595-604.

García, F.O., González Sanjuan, M.F., 2016. Consumo de fertilizantes en el mundo y en la Argentina. In: Lavado, R.S. (Ed.), Sustentabilidad de los agrosistemas y uso de fertilizantes. Orientación Grafica Editora-AACS-Fertilizar AC, Buenos Aires, Argentina, pp. 61-84 ISBN 978-987-1922-18-5.

García, F., Fabrizzi, K., Picone, L., Justel, F., 1999. Volatilización de amoniaco a partir de fertilizantes nitrogenados aplicados superficialmente bajo siembra directa y labranza convencional. Proceedings $14^{\circ}$ Latin-American Soil Science Congress. Pucón, Chile. 8-12 November 1999.

Grassini, P., Cassman, K.G., 2012. High-yield maize with large net energy yield and small global warming intensity. Proc. Natl. Acad. Sci. USA. 109, 1074-1079.

Groffman, P.M., Butterbach-Bahl, K., Fulweiler, R.W., Gold, A.J., Morse, J.L., Stander, E.K., Tague, C., Tonitto, C., Vidon, P., 2009. Challenges to incorporating spatially and temporally explicit phenomena (hot spots and hot moments) in denitrification models. Biogeochem. 93, 49-77.

Guo, X., Drury, C.F., Yang, X., Reynolds, W.D., Fan, R., 2014. The extent of soil drying and rewetting affects nitrous oxide emissions, denitrification, and nitrogen mineralization. Soil Sci. Soc. Am. J. 78 (194), 204.

Han, Z., Walter, M.T., Drinkwater, L.E., 2017. $\mathrm{N}_{2} \mathrm{O}$ emissions from grain cropping systems: a meta-analysis of the impacts of fertilizer-based and ecologically-based nutrient management strategies. Nutr. Cycl. Agroecosyst. 107, 335-355.

IPCC, 2007. Climate change 2007. Synthesis report. In: Core Writing Team, Pachauri, R.K., Reisinger, A. (Eds.), Contribution of Working Groups I, II \& III to the Fourth Assessment Report of the Intergovernmental Panel on Climate Change. Intergovernmental Panel on Climate Change, Geneva, Switzerland, p. 104.

IPCC, 2019. Climate change and land. An IPCC special report on climate change, desertification, land degradation, sustainable land management, food security, and greenhouse gas fluxes in terrestrial ecosystems. Intergovernmental Panel on Climate Change, Geneva, Switzerland https://www.ipcc.ch/site/assets/uploads/2019/08/ Fullreport-1.pdf.

IPNI, 2012. 4R plant nutrition: a manual for improving the management of plant nutrition. In: Bruulsema, T.W., Fixen, P.E., Sulewski, G.D. (Eds.), International Plant Nutrition Institute. Norcross, GA, USA.

Jacinthe, P.A., Dick, W.A., 1997. Soil management and nitrous oxide emissions from cultivated fields in Southern Ohio. Soil Till. Res. 41, 221-235.

Jantalia, C.P., Henrique, P., Sdos Santos, H.P., Urquiaga, S., Boddey, R.M., Alves, B.J.R., 2008. Fluxes of nitrous oxide from soil under different crop rotations and tillage systems in the South of Brazil. Nutr. Cycl. Agroecosyst. 82, 161-173.

Johnson, J.M.F., Franzluebbers, A.J., Lachnicht Weyers, S., Reicosky, D.C., 2007. Agricultural opportunities to mitigate greenhouse gas emissions. Environ. Pollut. 150, 107-124.

Keeney, D.R., Nelson, D.W., 1982. Nitrogen-inorganic forms. In: Page, A.L., Miller, R.H., Keeney, D.R. (Eds.), Methods of Soil Analysis. Part 2: Chemical and Microbiological Properties, 2nd ed Agronomy. Monograph 9. Soil Science Society of America, American Society of Agronomy, Madison, WI, pp. 643-698.

Lal, R., 2019. Eco-intensification through soil carbon sequestration: Harnessing ecosystem services and advancing sustainable development goals. J. Soil Water Cons. 74, 55A-61A. https://doi.org/10.2489/jswc.74.3.55A.

Lewczuk, N., Posse, G., Richter, K., Achkar, A., 2017. $\mathrm{CO}_{2}$ and $\mathrm{N}_{2} \mathrm{O}$ flux balance on soybean fields during growth and fallow periods in the Argentine Pampas-A study case. Soil Till. Res. 169, 65-70.
Linn, D.M., Doran, J.W., 1984. Effect of water-filled pore space on carbon dioxide and nitrous oxide: production in tilled and non-tilled soils. Soil Sci. Soc. Am. J. 48, 1267-1272.

Maharjan, B., Venterea, R.T., Rosen, C., 2014. Fertilizer and irrigation management effects on nitrous oxide emissions and nitrate leaching. Agron. J. 106, 703-714.

Manuel-Navarrete, D., Gallopin, G.C., Blanco, M., Diaz Zorita, M., Ferraro, D.O., Herzer, H., Laterra, P., Murmis, M.R., Podesta, G.P., Ravinovich, I., Satorre, E.H., Torres, F., Viglizzo, E.F., 2009. Multi-causal and integrated assessment of sustainability: the case of agriculturization in the Argentine Pampas. Environ. Dev. Sustain. 11, 621-638.

Norton, R., Davidson, E., Roberts, T.L., 2015. Nitrogen Use Efficiency and Nutrient Performance Indicators. GPNM Task Team Report and Recommendations. Technical Paper 01/2015. GPNM, Washington, DC, USA.

OECD/FAO, 2018. OECD-FAO Agricultural Outlook 2018-2027. OECD Publishing, Paris/ Food and Agriculture Organization of the United Nations, Rome https://doi.org/ 10.1787/agr_outlook-2018-en accessed on14 March 2018.

Omonode, R.A., Smith, D.R., Gál, A., Vyn, T.J., 2010. Soil nitrous oxide emissions in maize following three decades of tillage and rotation treatments. Soil Sci. Soc. Am. J. 75, $152-163$.

Omonode, R.A., Halvorson, A.D., Gagnon, B., Vyn, T.J., 2017. Achieving lower nitrogen balance and higher nitrogen recovery efficiency reduces nitrous oxide emissions in North America's maize cropping systems. Front. Plant Sci. 8. https://doi.org/ 10.3389/fpls.2017.01080 Article 1080.

Parkin, T.B., 2008. Effect of sampling frequency on estimates of cumulative nitrous oxide emissions. J. Environ. Qual. 37, 1390-1395.

Parkin, T.B., Kaspar, T.C., 2006. Nitrous oxide emissions from maize-soybean systems in the Midwest. J. Environ. Qual. 35, 1496-1506.

Parkin, T.B., Venterea, R.T., 2010. USDA-ARS GRACEnet Project Protocols. Chapter 3. Chamber-based trace gas flux measurements. In: Follett, R.F. (Ed.), Sampling Protocols. Beltsville, MD, pp. 1-39.

Pelster, D.E., Larouche, F., Rochette, P., Chantigny, M.H., Allaire, S., Angers, D.A., 2011. Nitrogen fertilization but not soil tillage affects nitrous oxide emissions from a clay loam soil under a maize-soybean rotation. Soil Till. Res. 115-116, 16-26.

R Core Team, 2016. R: A language and environment for statistical computing. R Foundation for Statistical Computing, Vienna, Austria http://R-project.org.

Reatto, A., Bruand, A., Silva, E.M., Guéganl, R., Cousin, I., Brossard, M., Martins, E.S., 2009. Shrinkage of microaggregates in Brazilian latosols during drying: Significance of the clay content, mineralogy and hydric stress history. Eur. J. Soil Sci. 60, 1106-1116.

Rochette, P., Angers, D.A., Chantigny, M.H., Bertrand, N., 2004. Carbon dioxide and nitrous oxide emissions following fall and spring applications of pig slurry to an agricultural soil. Soil Sci. Soc. Am. J. 68, 1410-1420.

Sadras, V.O., Cassman, K.G., Grassini, P., Hall, A.J., Bastiaanssen, W.G.M., Laborte, A.G. Milne, A.E., Sileshi, G., Steduto, P., 2015. Yield Gap Analysis of Field Crops - Methods and Case Studies. Water Reports No. 41. FAO, Rome, Italy http://www.fao.org/3/ai4695e.pdf.

SAGPyA, 2018. Secretaria de Agroindustria. http://datosestimaciones.magyp.gob.ar/ reportes.php?reporte=Estimaciones [accessed: july 2018].

Sainz Rozas, H.R., Echeverría, H.E., Studdert, G.A., Andrade, F.H., 1999. No-tillage maize nitrogen uptake and yield: effect of urease inhibitor and application time. Agron. J. 91, 950-955.

Sainz Rozas, H., Echeverría, H.E., Picone, L.I., 2001. Denitrification in maize under notillage: effect of nitrogen rate and application time. Soil Sci. Soc. Am. J. 65, 1314-1323.

Skiba, U., Fowler, D., Smith, K., 1994. Emissions of $\mathrm{NO}$ and $\mathrm{N}_{2} \mathrm{O}$ from soils. Environ. Monit. Assess. 31, 153-158.

Snyder, C.S., Bruulsema, T.W., Jensen, T.L., Fixen, P.E., 2009. Review of greenhouse gas emissions from crop production systems and fertilizer management effects. Agr. Ecosyst. Environ. 133, 247-266.

Stehfest, E., Bouwman, L., 2006. $\mathrm{N}_{2} \mathrm{O}$ and $\mathrm{NO}$ emission from agricultural fields and soils under natural vegetation: Summarizing available measurement data and modeling of global annual emissions. Nutr. Cycl. Agroecosys. 74, 207-228.

Sutton, M.A., Bleeker, A., Howard, C.M., Bekunda, M., Grizzetti, B., de Vries, W., van Grinsven, H.J.M., Abrol, Y.P., Adhya, T.K., Billen, G., Davidson, E.A., Datta, A., Diaz, R., Erisman, J.W., Liu, X.J., Oenema, O., Palm, C., Raghuram, N., Reis, S., Scholz, R.W., Sims, T., Westhoek, H., Zhang, F.S., 2013. Our Nutrient World: The challenge to produce more food and energy with less pollution. Global Overview on Nutrient Management. Centre for Ecology and Hydrology, Edinburgh, UK, p. 114.

Tillman, D., Balzer, C., Hill, J., Befort, B.L., 2011. Global food demand and the sustainable intensification of agriculture. Proc. Natl Acad. Sci. 108, 20260-20264. https://doi. org/10.1073/pnas.1116437108.

UNEP, 2014. Assessing global land use: Balancing consumption with sustainable supply. In: Bringezu, S., Schütz, H., Pengue, W., O’Brien, M., Garcia, F., Sims, R., Herrick, J. (Eds.), A report of the working group on land and soils of the international resource panel, p. 46 Job Number: DTI/1658/PA. ISBN: 978-92-807-3330-3. Paris, France.

Van Groenigen, J.W., Velthof, G.L., Oenema, O., Van Groenigen, K.J., Van Kessel, C., 2010 Towards an agronomic assessment of $\mathrm{N}_{2} \mathrm{O}$ emissions: a case study for arable crops. Eur. J. Soil Sci. 61, 903-913.

van Ittersum, M.K., Cassman, K.G., Grassini, P., Wolf, J., Tittonell, P., Hochman, Z., 2015. Yield gap analysis with local to global relevance-a review. Field Crops Res. 143, 4-17. https://doi.org/10.1016/j.fcr.2012.09.009.

Venterea, R.T., 2010. Simplified method for quantifying theoretical underestimation of chamber-based trace gas fluxes. J. Environ. Qual. 39, 126-135.

Venterea, R.T., Maharjan, B., Dolan, M.S., 2011. Fertilizer source and tillage effects on yieldscaled nitrous oxide emissions in a maize cropping system. J. Environ. Qual. 40, 1521-1531. 
Venterea, R.T., Coulter, J.A., Dolan, M.S., 2016. Evaluation of intensive "4R" strategies for decreasing nitrous oxide emissions and nitrogen surplus in rainfed maize. J. Environ. Qual. 45, 1186-1195.

Voroney, R.P., Heck, R.J., 2015. The soil habitat. In: Paul, E.A. (Ed.), Soil microbiology, ecology and biochemistry, Fourth edition Academic Press, Boston, pp. 15-39.

Wagner-Riddle, C., Hu, Q.C., van Bochove, E., Jayasundara, S., 2008. Linking nitrous oxide flux during spring thaw to nitrate denitrification in the soil profile. Soil Sci. Soc. Am. J. 72, 908-916.
Wingeyer, A.B., Amado, T.J.C., Bidegain, M.P., Studdert, G.A., Perdomo Varela, C.H., Garcia, F.O., Karlen, D.L., 2015. Soil quality impacts of current South American agricultural practices. Sustainability 7, 2213-2242.

Zhao, R., He, P., Xie, J., Johnston, A.M., Xu, X., Qiu, S., Zhao, S., 2016. Ecological intensification management of maize in northeast China: agronomic and environmental response. Agric. Ecosyst. Environ. 224, 123-130.

Zhao, X., Nafziger, E.D., Pittelkow, C.M., 2017. Nitrogen rate strategies for reducing yieldscaled nitrous oxide emissions in maize. Environ. Res. Lett. 12, 124006. 